Prepared in cooperation with the New Mexico Department of Homeland Security and Emergency Management

\title{
Calibration of Precipitation-Runoff Modeling System (PRMS) to Simulate Prefire and Postfire Hydrologic Response in the Upper Rio Hondo Basin, New Mexico
}

Scientific Investigations Report 2019-5022 



\section{Calibration of Precipitation-Runoff Modeling System (PRMS) to Simulate Prefire and Postfire Hydrologic Response in the Upper Rio Hondo Basin, New Mexico}

By Kyle R. Douglas-Mankin and C. David Moeser

Prepared in cooperation with the New Mexico Department of Homeland Security and Emergency Management

Scientific Investigations Report 2019-5022 


\title{
U.S. Department of the Interior \\ DAVID BERNHARDT, Secretary
}

\author{
U.S. Geological Survey \\ James F. Reilly II, Director
}

U.S. Geological Survey, Reston, Virginia: 2019

For more information on the USGS - the Federal source for science about the Earth, its natural and living resources, natural hazards, and the environment-visit https://www.usgs.gov or call 1-888-ASK-USGS.

For an overview of USGS information products, including maps, imagery, and publications,

visit https://store.usgs.gov.

Any use of trade, firm, or product names is for descriptive purposes only and does not imply endorsement by the U.S. Government.

Although this information product, for the most part, is in the public domain, it also may contain copyrighted materials as noted in the text. Permission to reproduce copyrighted items must be secured from the copyright owner.

Suggested citation:

Douglas-Mankin, K.R., and Moeser, C.D., 2019, Calibration of Precipitation-Runoff Modeling System (PRMS) to simulate prefire and postfire hydrologic response in the upper Rio Hondo Basin, New Mexico: U.S. Geological Survey Scientific Investigations Report 2019-5022, 25 p., https://doi.org/10.3133/sir20195022.

ISSN 2328-0328 (online) 


\section{Contents}

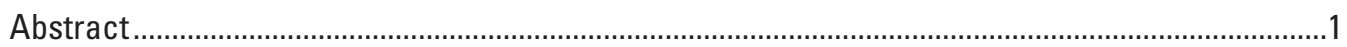

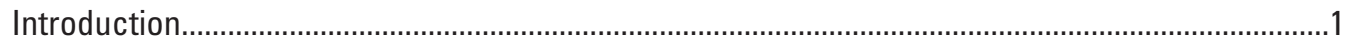

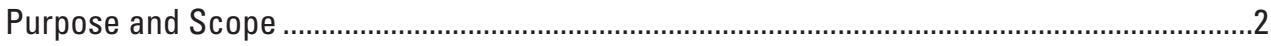

Description of Study Area .................................................................................................2

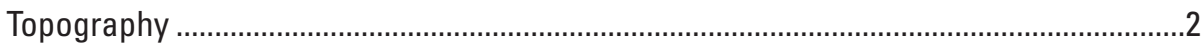

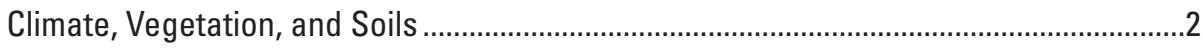

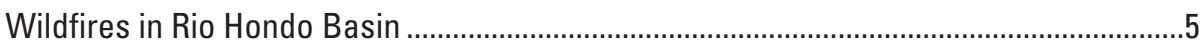

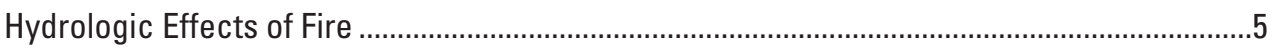

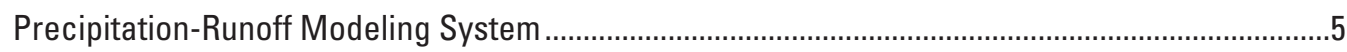

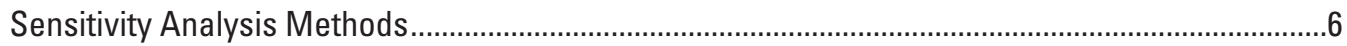

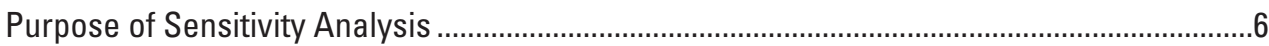

Fourier Amplitude Sensitivity Test............................................................................................

Fourier Amplitude Sensitivity Test Interface ……………….......................................................

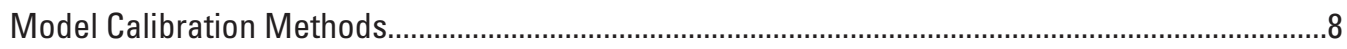

Purpose of Calibration ........................................................................................................

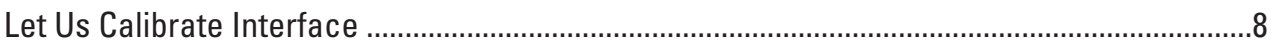

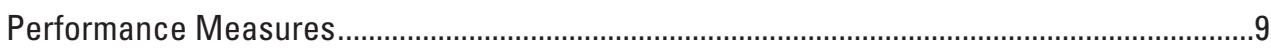

PRMS Model Sensitivity Analysis for Upper Rio Hondo Basin ........................................................

Sensitivity in Upper Rio Hondo Basin ...............................................................................

Sensitivity in the North Fork Eagle Creek Subwatershed ...................................................13

PRMS Model Calibration for the North Fork Eagle Creek Subwatershed........................................13

Meteorological Data .................................................................................................... 14

Baseline Prefire Parameter Adjustments .........................................................................14

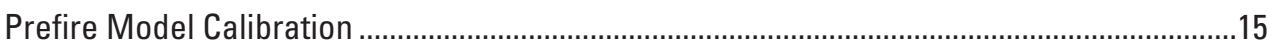

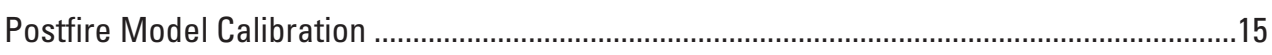

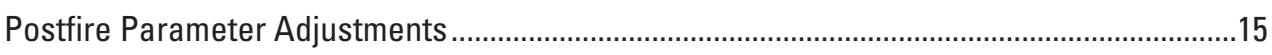

Discussion and Application of Prefire and Postfire Models ...........................................................19

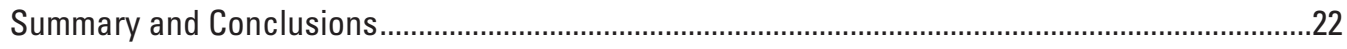

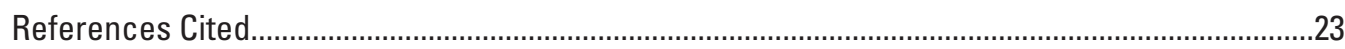

\section{Figures}

1. Map showing the upper Rio Hondo Basin study area, Lincoln and Otero Counties, New Mexico

2. Map showing the upper Rio Hondo Basin study area, precipitation-runoff modeling system hydrologic response unit boundaries, U.S. Geological Survey streamgage locations, and historical fire boundaries...

3. Maps showing hydrologic process with greatest sensitivity to each of three streamflow statistics by hydrologic response unit, upper Rio Hondo Basin, New Mexico

4. Maps showing normalized process sensitivity for three streamflow statistics by hydrologic response unit, upper Rio Hondo Basin, New Mexico

5. Maps showing normalized process sensitivity for three streamflow statistics by hydrologic response unit and model parameter, upper Rio Hondo Basin, New Mexico 
6. Graph showing daily simulated and observed streamflow and precipitation for the study period for the North Fork Eagle Creek subwatershed, New Mexico.

7. Graphs showing observed and simulated streamflow and observed precipitation at the Cloudcroft raingage for prefire and postfire conditions, June through November, North Fork Eagle Creek subwatershed, New Mexico.

8. Graphs showing observed streamflow and the calibrated Precipitation-Runoff Modeling System cumulative daily streamflow for prefire and postfire conditions, June through November, North Fork Eagle Creek subwatershed, New Mexico

9. Graph showing annual total streamflow component contributions for prefire and postfire calibrated Precipitation-Runoff Modeling System models

\section{Tables}

1. Precipitation-Runoff Modeling System calibration parameters.

2. U.S. Geological Survey streamgages in the upper Rio Hondo Basin and descriptions, including drainage area, elevation, and beginning and ending dates of the period of record

3. Model baseline parameters adjusted manually prior to calibration and calibrated parameters adjusted using the Let Us Calibrate algorithm for prefire and postfire simulations in the North Fork Eagle Creek subwatershed.

4. User-specified Let Us Calibrate parameters for prefire calibration run in the North Fork Eagle Creek subwatershed, New Mexico

5. Model performance measures for initial parameters and calibrated parameters at the monthly time-step for prefire and postfire streamflow during summer-fall in the North Fork Eagle Creek subwatershed

6. User-specified Let Us Calibrate parameters for postfire calibration run in the North Fork Eagle Creek subwatershed

7. Initial and assigned model parameter values to represent changes in forest cover after fire..... 


\section{Conversion Factors}

U.S. customary units to International System of Units

\begin{tabular}{|c|c|c|}
\hline Multiply & By & To obtain \\
\hline \multicolumn{3}{|c|}{ Length } \\
\hline inch (in.) & 2.54 & centimeter (cm) \\
\hline inch (in.) & 25.4 & millimeter (mm) \\
\hline foot (ft) & 0.3048 & meter $(\mathrm{m})$ \\
\hline mile (mi) & 1.609 & kilometer (km) \\
\hline \multicolumn{3}{|c|}{ Area } \\
\hline acre & 0.4047 & hectare (ha) \\
\hline acre & 0.004047 & square kilometer (km²) \\
\hline square mile $\left(\mathrm{mi}^{2}\right)$ & 259.0 & hectare (ha) \\
\hline square mile $\left(\mathrm{mi}^{2}\right)$ & 2.590 & square kilometer $\left(\mathrm{km}^{2}\right)$ \\
\hline \multicolumn{3}{|c|}{ Volume } \\
\hline cubic foot $\left(\mathrm{ft}^{3}\right)$ & 0.02832 & cubic meter $\left(\mathrm{m}^{3}\right)$ \\
\hline acre-foot (acre-ft) & 1,233 & cubic meter $\left(\mathrm{m}^{3}\right)$ \\
\hline \multicolumn{3}{|c|}{ Flow rate } \\
\hline cubic foot per second $\left(\mathrm{ft}^{3} / \mathrm{s}\right)$ & 0.02832 & cubic meter per second $\left(\mathrm{m}^{3} / \mathrm{s}\right)$ \\
\hline inch per year (in/yr) & 25.4 & millimeter per year (mm/yr) \\
\hline
\end{tabular}

Temperature in degrees Celsius $\left({ }^{\circ} \mathrm{C}\right)$ may be converted to degrees Fahrenheit $\left({ }^{\circ} \mathrm{F}\right)$ as follows:

$$
{ }^{\circ} \mathrm{F}=\left(1.8 \times{ }^{\circ} \mathrm{C}\right)+32 .
$$

Temperature in degrees Fahrenheit $\left({ }^{\circ} \mathrm{F}\right)$ may be converted to degrees Celsius $\left({ }^{\circ} \mathrm{C}\right)$ as follows:

$$
{ }^{\circ} \mathrm{C}=\left({ }^{\circ} \mathrm{F}-32\right) / 1.8 \text {. }
$$

\section{Datum}

Vertical coordinate information is referenced to the North American Vertical Datum of 1988 (NAVD 88) in figures 1 and 2 and to the National Geodetic Vertical Datum of 1929 (NGVD 29) in table 2.

Horizontal coordinate information is referenced to the North American Datum of 1983 (NAD 83). 


\section{Abbreviations}

$\begin{array}{ll}\text { AR-1 } & \text { Autoregressive lag-1 correlation coefficient } \\ \text { CV } & \text { Coefficient of variation } \\ \text { ET } & \text { Evapotranspiration } \\ \text { FAST } & \text { Fourier amplitude sensitivity test } \\ \text { HRU } & \text { Hydrologic response unit } \\ \text { HUC } & \text { Hydrologic unit code } \\ \text { LUCA } & \text { Let Us Calibrate } \\ \text { NHM } & \text { National Hydrologic Model } \\ \text { NMDHSEM } & \text { New Mexico Department of Homeland Security and Emergency Management } \\ \text { NRMSE } & \text { Normalized root-mean-square error } \\ \text { NSE } & \text { Nash-Sutcliffe model efficiency } \\ \text { PRMS } & \text { Precipitation-Runoff Modeling System } \\ R^{2} & \text { Coefficient of determination } \\ \text { RMSE } & \text { Root-mean-square error } \\ \text { RSR } & \text { Ratio of RMSE to standard deviation } \\ \text { USGS } & \text { U.S. Geological Survey }\end{array}$




\title{
Calibration of Precipitation-Runoff Modeling System (PRMS) to Simulate Prefire and Postfire Hydrologic Response in the Upper Rio Hondo Basin, New Mexico
}

\author{
By Kyle R. Douglas-Mankin and C. David Moeser
}

\section{Abstract}

The Precipitation-Runoff Modeling System (PRMS) is widely used to simulate the effects of climate, topography, land cover, and soils on landscape-level hydrologic responses and streamflow. The U.S. Geological Survey (USGS), in cooperation with the New Mexico Department of Homeland Security and Emergency Management, developed procedures to apply the PRMS model to simulate the effects of fire on hydrologic responses.

A PRMS model was built of the upper Rio Hondo Basin from the headwaters to approximately 19 miles downstream from the USGS streamgage Rio Hondo above Chavez Canyon near Hondo, New Mexico, by using 24 hydrologic response units (HRUs), or hydrologically similar subareas, from the National Hydrologic Model. A quasi-graphical user interface was created to easily query and analyze published PRMS sensitivity-analysis data. Simulation of mean daily streamflow was most sensitive to parameters related to snowmelt or infiltration throughout the upper Rio Hondo Basin. In the basin's eastern and northern HRUs, flashiness and timing of streamflow were most sensitive to interflow; in many western-basin HRUs (higher elevations), flashiness of streamflow was most sensitive to soil moisture parameters, and timing of streamflow was most sensitive to infiltration and evapotranspiration parameters.

The PRMS model was calibrated for the fire-affected North Fork Eagle Creek subwatershed by comparing modeled to observed daily streamflow for the nonfrozen (May through October) period for a prefire and postfire time period. The prefire model was calibrated for the period 2007-12 before the 2012 fire, and the postfire model was calibrated for a 2-year (2014-15) period after the fire. Model parameterization combined manual adjustment of 8 parameters on the basis of prior knowledge and automated adjustment of the most sensitive parameters by using the Let Us Calibrate interface. A gridded, daily precipitation dataset that captured the spatial heterogeneity across the study watershed was used as the precipitation input for calibration. Model performance was assessed as satisfactory by using standard statistical measures for prefire and postfire periods.

The calibrated model was run by using data from a single precipitation gage to better represent the effect of localized, extreme storms on postfire hydrologic response. The calibrated models for prefire and postfire conditions simulated streamflows with greater consistency than the uncalibrated model for the corresponding (prefire or postfire) period of hydrographic record. The effect of fire on streamflow was found to be primarily a shift from streamflow dominated by base flow prior to fire to streamflow dominated by surface runoff after fire.

\section{Introduction}

Wildfire is a natural watershed process that is important for ecological health and sustainability of land resources. A complex connection exists between humans and wildfire because wildfire can not only be altered by human activities but also have effects on human life and property (Moody and others, 2013). In addition to the often devastating impacts of the fire itself, postfire effects, including increased flooding and debris flows in addition to slow landscape recovery processes, can have important ramifications on communities dependent upon the fire-affected regions (Liu and others, 2010).

Postfire effects on watershed hydrologic processes and streamflow can vary greatly and are dependent on many watershed-specific and fire-specific factors (Konrad, 2004). Watershed models are widely used to simulate the effects of current and future climate, land characteristics, and management or disturbance on hydrologic responses and could be adapted to understand watershed-scale effects of fire. Results of postfire watershed model simulations can provide critical information for watershed, water-supply, and emergency planning and management decisions. 
A major fire occurred in June 2012 in the upper Rio Hondo Basin in south-central New Mexico following record drought conditions in 2011 and 2012 (Sherson and Rice, 2015). The 2012 Little Bear Fire burned approximately 69 square miles $\left(\mathrm{mi}^{2}\right)(44,300$ acres) in the high-elevation forests of the upper Rio Bonito and Eagle Creek watersheds (Snyder and others, 2012). In response to this fire, the New Mexico Department of Homeland Security and Emergency Management (NMDHSEM) worked with the U.S. Geological Survey (USGS) to install precipitation gages as a part of an early warning system within fire-affected areas to help protect life and property. The precipitation gages provide real-time data on rainfall intensity that can be used to alert susceptible downstream populations about potential flooding. The USGS, in cooperation with NMDHSEM, also initiated a study to improve the understanding of the effects of fire on watershed processes and to provide relevant hydrologic information that can be used to guide the sustainable preservation and management of the affected water resources.

\section{Purpose and Scope}

The purpose of this report was to examine the extent to which the Precipitation-Runoff Modeling System (PRMS) can accurately represent the effects of fire on watershed-scale hydrologic response. This report describes the development, sensitivity analysis, calibration, and implementation of PRMS to simulate the prefire and postfire streamflow and surface hydrologic conditions of the fire-affected North Fork Eagle Creek subwatershed in the upper Rio Hondo Basin. Data associated with this report can be found in Moeser and others (2018).

\section{Description of Study Area}

The upper Rio Hondo Basin (fig. 1) has been described in detail by Tillery and Matherne (2013), Darr and others (2014), and Sherson and Rice (2015) and is briefly described in this section.

The focus of this study was the fire-burned areas (fig. 2) of the North Fork Eagle Creek subwatershed area of the upper Rio Hondo Basin. The following general descriptions of the upper Rio Hondo Basin help provide context for the PRMS model sensitivity analysis, which was conducted at the basin scale. Additional details of the North Fork Eagle Creek subwatershed help provide context for the prefire and postfire PRMS model calibrations, which were conducted at the subwatershed scale. The North Fork Eagle Creek subwatershed has characteristics of the higher elevation forested areas of the Sacramento Mountains (fig. 1).

\section{Topography}

The upper Rio Hondo Basin encompasses $931 \mathrm{mi}^{2}$ (596,160 acres) in south-central New Mexico within Lincoln and Otero Counties, bounded on the north by the Capitan Mountains and on the west and south by the Sacramento Mountains (fig. 1). Basin elevation ranges from 11,981 feet ( $\mathrm{ft}$ ) in the Sierra Blanca range on the western edge of the study area to about $4,475 \mathrm{ft}$ at the basin outlet, located about 19 miles (mi) downstream from the USGS streamgage Rio Hondo above Chavez Canyon near Hondo, New Mexico (08390020). Surface water generally flows eastward. The primary source of streamflow in the study area is precipitation originating at high elevations in the Sacramento and Capitan Mountains (Darr and others, 2014). The basin includes two major rivers: Rio Bonito in the northern part of the basin is mostly perennial in the headwaters, becoming intermittent in the lower elevations, whereas Rio Ruidoso in the southern part of the basin is mostly perennial. The North Fork Eagle Creek subwatershed, above the town of Alto in the upper Rio Ruidoso watershed, is also perennial. The upper Eagle Creek subwatershed $\left(8.17 \mathrm{mi}^{2}\right)$ includes the North Fork $\left(5.38 \mathrm{mi}^{2}\right)$ and South Fork $\left(2.79 \mathrm{mi}^{2}\right)$ Eagle Creek subwatersheds.

\section{Climate, Vegetation, and Soils}

The Köppen-Geiger climate classification uses three letters to characterize world climates based on vegetation group (first letter), precipitation (second letter), and air temperature (third letter) (Kottek and others, 2006). Climate in the lower elevation areas of the eastern upper Rio Hondo Basin is BSk, which is an arid steppe climate with cold subclassification (mean annual temperature $<64.4$ degrees Fahrenheit $\left[{ }^{\circ} \mathrm{F}\right]$ ) (using 1951-2000 data). In the higher elevation areas of the western basin, classification is either $\mathrm{Cfb}$ (using 1986-2010 data), which is a warm, temperate, fully humid climate with warm summers, or Csb (using 1951-2000 data), which is a warm, temperate, dry summer climate with warm summers (Kottek and others, 2006; Rubel and others, 2017). The BSk climate classification pervades much of the lower elevation regions of New Mexico. The Csb and $\mathrm{Cfb}$ classifications are in many of the mountainous regions of New Mexico that fall outside the classification of a snow climate (group D in the Köppen-Geiger climate classification).

Total annual precipitation varies spatially throughout the study area depending on elevation, ranging from 15 inches per year (in/yr) in the eastern lowland areas and valleys to $40 \mathrm{in} / \mathrm{yr}$ at high elevations (Matherne and others, 2010; Darr and others, 2014). Mean monthly precipitation data indicate that a majority of the precipitation falls during the summer months (June-September) as monsoon storms (Sherson and Rice, 2015). Summer precipitation accounts for an average of 59 percent of the total annual precipitation for the period 1942-2013 (Sherson and Rice, 2015). Snowpack in the study area typically reaches the maximum snow-water equivalent in February and March, followed by a rapid melt period in April and May (Sherson and Rice, 2015).

Vegetation is dominated by mixed conifer forests interspersed with grasslands at higher elevations; Pinus edulis-Juniperus sp. (piñon pine-juniper) and Pinus ponderosa 


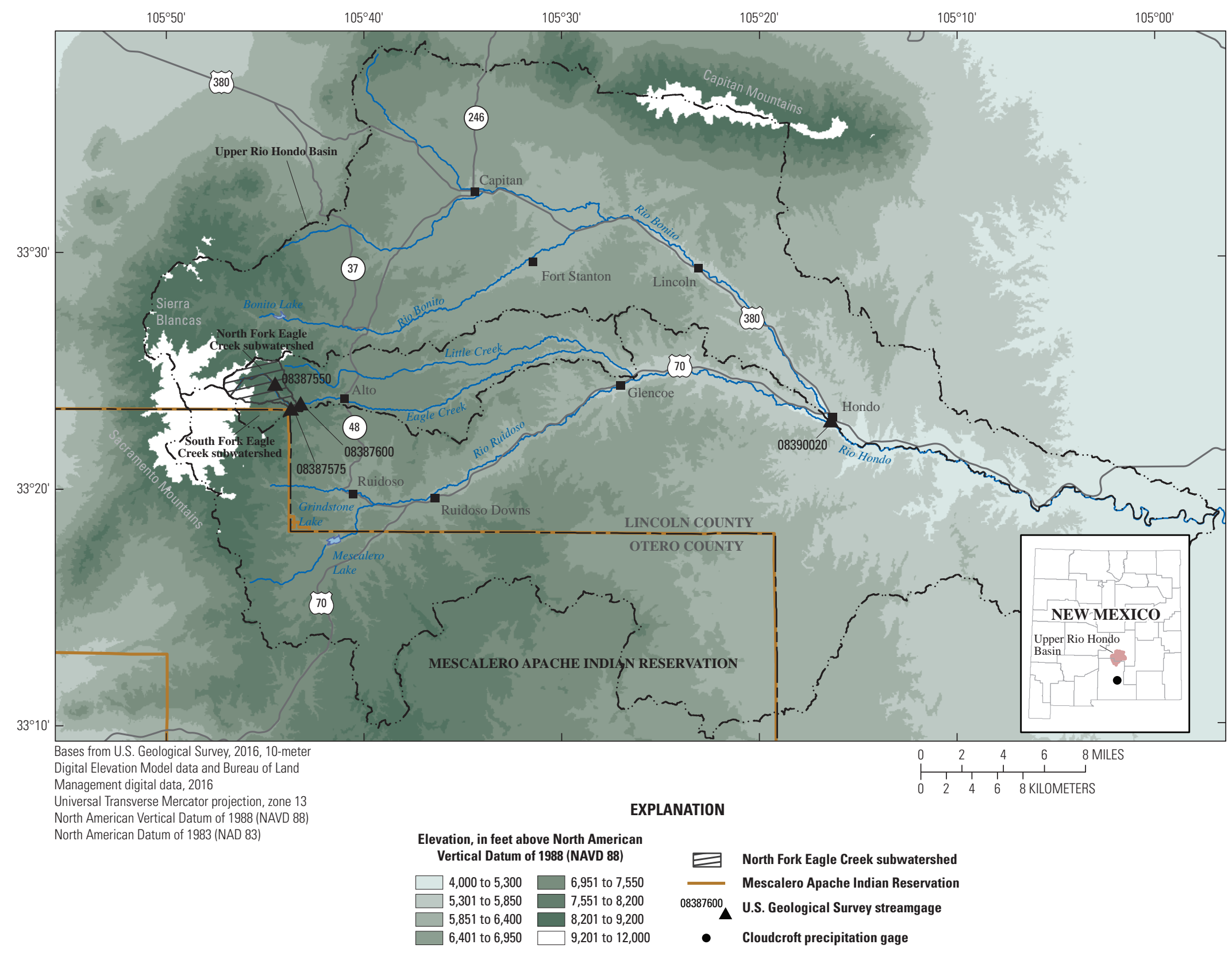

Figure 1. Upper Rio Hondo Basin study area, Lincoln and Otero Counties, New Mexico. 


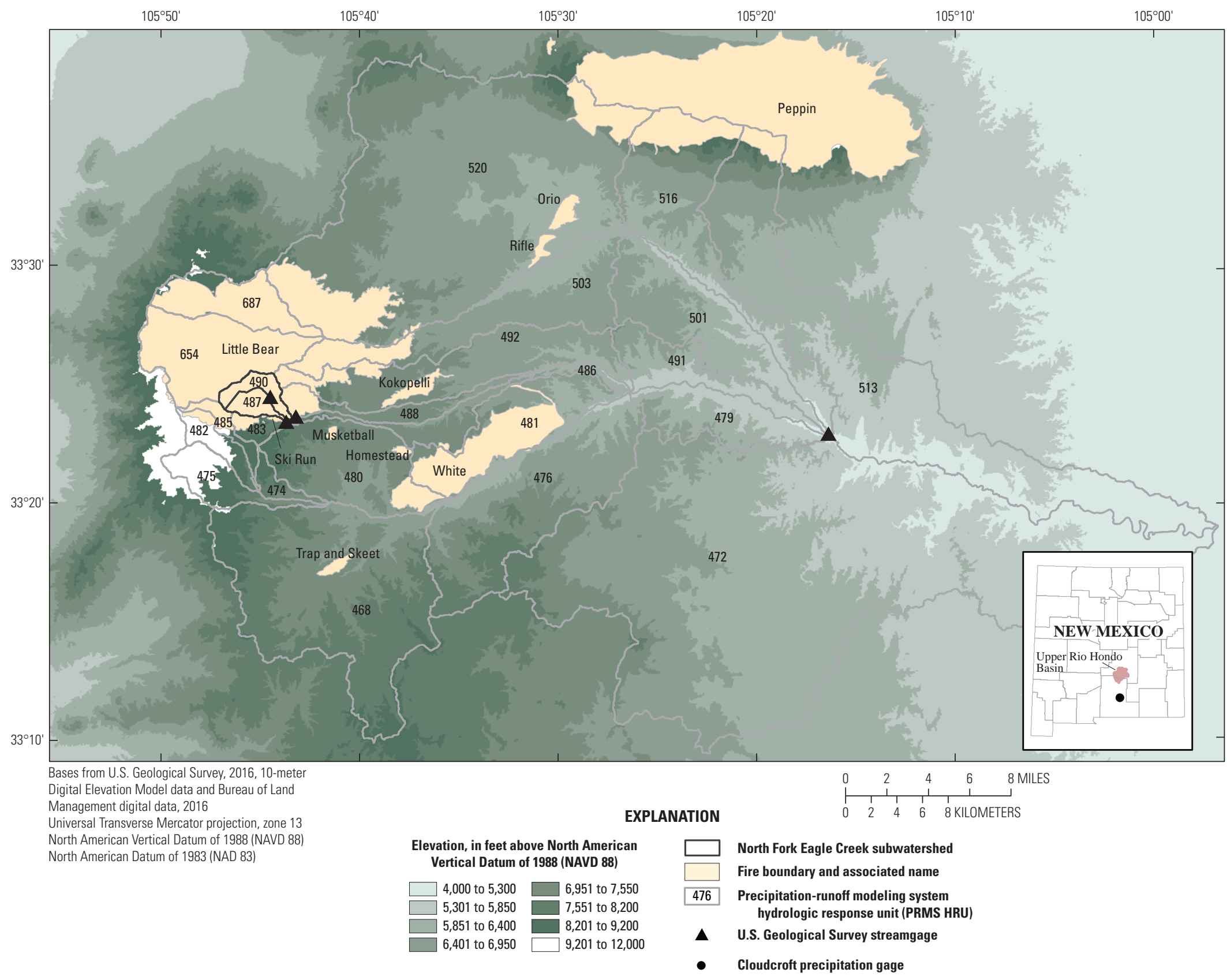

Figure 2. Upper Rio Hondo Basin study area, precipitation-runoff modeling system (PRMS) hydrologic response unit (HRU) boundaries (Viger and Bock, 2014), U.S. Geological Survey streamgage locations, and historical fire boundaries (2000-14; U.S. Geological Survey, 2018a). 
(ponderosa pine) forests at mid-elevations; and desert grasses, cacti, and shrubs at lower elevations (Sherson and Rice, 2015). Historically, the forested areas in the western part of the upper Rio Hondo Basin contained a tree density varying from 20 to 70 trees per acre with grass-dominated understories. However, decades of fire suppression led to establishment of dense forests with 200 to 250 trees per acre with increased litter, little grass, and fewer openings (Wisner, 2004).

Soil-zone data from the Soil Survey Geographic Database (U.S. Department of Agriculture, https://sdmdataaccess. sc.egov.usda.gov, accessed June 25,2017 ) were not available for a substantial part of the mountainous areas in the upper Rio Hondo Basin, including the North Fork Eagle Creek subwatershed, so a precise description of soils in the overall basin and the target subwatershed is not possible. Data are available for about two-thirds of the South Fork Eagle Creek subwatershed (Natural Resources Conservation Service, U.S. Department of Agriculture, 2012). Soils in the "Firo very stony loam" and "Firo-Stony land complex," which represent a majority of the South Fork Eagle Creek subwatershed area, are well-drained soils in the "very high" runoff class, are classified as hydrologic soil group D, and typically have a very stony loam or stony loam surface soil layer $(0-3$ inches [in.]), a very cobbly loam underlying layer (3-15 in.), and a depth to restrictive layer of 7-20 in. A substantial portion of the remaining soils are Caballo loam, which are well-drained soils in the "high" runoff class, are classified as hydrologic soil group B, and typically have a loam surface soil layer (0-10 in.), an extremely cobbly clay loam underlying layer (10-42 in.), and a depth to restrictive layer of more than $80 \mathrm{in.}$ In the middle part of the upper Rio Hondo Basin, roughly from Ruidoso to Capitan (fig. 1), soils are in the "well-drained" drainage class, have hydrologic soil groups of predominantly $\mathrm{D}$ (about 33 percent) and $\mathrm{C}$ (about 50 percent), and have depths to restrictive layer exceeding $6.5 \mathrm{ft}$ (about 67 percent), with the remaining area evenly split between the $0-1.6-\mathrm{ft}$ and 1.6-3.3-ft depths. In the lower part of the basin, roughly from Capitan to the basin outlet at the convergence of the Rio Bonito and Rio Ruidoso (fig. 1), soils are in the "well-drained" drainage class, have hydrologic soil groups of predominantly $\mathrm{D}$ (almost 90 percent) and C (about 10 percent), and have depths to restrictive layer of $1.6-3.3 \mathrm{ft}$ (almost 80 percent), with most of the remaining area exceeding 6.6-ft depths.

\section{Wildfires in Rio Hondo Basin}

Fire has long been a part of ecological systems in forested basins of the western United States. The upper Rio Hondo Basin was affected by 11 recorded fires from 2000 to 2014 (U.S. Geological Survey, 2018a). The Little Bear Fire (June 2012) was among the largest, having a total burned area of 44,300 acres, with 36,234 acres in the upper Rio Hondo Basin. Other fires in the upper Rio Hondo Basin include the following: Orio (2012, 827 acres), Donaldson (2011, 101,513 acres; not shown on figure 2, located approximately 6 mi south of Hondo, New Mexico),
White (2011, 10,348 acres), Rifle (2011, 458 acres), Peppin (2004, 47,863 acres), Ski Run (2003, 265 acres), Kokepelli (2002, 1,000 acres), Trap and Skeet (2001, 463 acres), Homestead (2001, 200 acres), and Musketball (2001, 152 acres). Two fires greatly affected the North Fork Eagle Creek subwatershed: Little Bear Fire (2012) burned the entire 2,020-acre subwatershed, and the Ski Run Fire (2003) burned 265 acres in the southern part of the subwatershed.

The Little Bear Fire originated in the high-elevation forests of the Sierra Blanca Range near the basin boundary of the North Fork Eagle Creek subwatershed and spread north and east into the Rio Hondo Basin, eventually burning $55 \mathrm{mi}^{2}$ (19 percent) of the Rio Bonito watershed and $14 \mathrm{mi}^{2}$ (5 percent) of the Rio Ruidoso watershed. Burn severity was high or moderate on 53 percent of the burn area (Snyder and others, 2012). About $11 \mathrm{mi}^{2}$ of upper Eagle Creek subwatershed was burned, including the entire North Fork Eagle Creek subwatershed.

\section{Hydrologic Effects of Fire}

Wildfires alter landscapes by burning groundcover, understory vegetation, and canopies and by altering physical, chemical, and biological properties of soil (Doerr and Cerda, 2005; Doerr and others, 2009; Terranova and others, 2009). Postfire landscapes have measurable hydrologic changes when compared to their prefire conditions, including reduced infiltration (Martin and Moody, 2001; Moody and Martin, 2001; Terranova and others, 2009), reduced evapotranspiration (ET) (Doerr and others, 2009), increased surface runoff (Cerda and Doerr, 2005; Terranova and others, 2009; Vieira and others, 2015), and increased peak streamflows (Moody and Martin, 2001). As a result, postfire landscapes are more susceptible to floods and debris flows, which threaten property and life. Postfire effects that contribute to increased surface runoff include decreased canopy cover, which reduces canopy interception and storage; decreased ground cover, which enhances raindrop splash erosion, soil aggregate dispersion, and soil pore closure and, thus, reduces infiltration; and increased soil water repellency, which reduces infiltration rates. Depending on fire severity and vegetation and soil disruption, recovery from fire effects may be measurable within 2 to 6 years (MacDonald and Stednick, 2003; MacDonald and Huffman, 2004; Cerda and Doerr, 2005; Vieira and others, 2015), but some effects may still be measurable after 10 years or more (Cerda and Doerr, 2005).

\section{Precipitation-Runoff Modeling System}

The PRMS is a component of the National Hydrologic Model (NHM), developed by the USGS (Leavesley and others, 1983; Markstrom and others, 2015). PRMS is a deterministic, processed-based, distributed-parameter modeling system designed to analyze the effects of 
precipitation, climate, and land use on streamflow and general basin hydrology on a daily time step. The national-scale framework of the NHM allows for subcatchment modeling by using predefined, spatially distributed hydrologic response units (HRUs). HRUs partition the model domain into areas with relatively uniform hydrologic response that are based on watershed topography, vegetation, soil, and climate. The model input data include precipitation, minimum temperature, and maximum temperature.

The PRMS model represents the hydrologic cycle as 17 interconnected processes represented within the model as separate modules (Markstrom and others, 2015). Hydrologic processes implemented in PRMS include temperature distribution, precipitation distribution, combined climate distribution, solar radiation distribution, transpiration period, potential ET, canopy interception, snow, surface runoff, soil zone, groundwater, and streamflow, plus five model administrative processes (basin definition, cascading flow, solar table, time series data, and summary).

Each module in PRMS operates by using parameters and variables to simulate hydrologic processes. Parameters are user-specified input values that are constant through time (year to year) and may vary spatially across the landscape (unique values per HRU), or may vary by month and HRU (giving unique values [HRUs $\times$ months]), but do not change during the simulation (for example, the area of each HRU). Variables are hydrologic states and fluxes that may vary with each time step during the simulation (Markstrom and others, 2015). Variables may be user-input, time-series variables (for example, daily precipitation) or internal variables (for example, soil moisture for each HRU), which are calculated by the modules and may be used by other modules as input variables.

PRMS, like most distributed hydrologic models, needs to be calibrated to be applicable to a specific study area. PRMS uses a total of 108 input parameters, but 74 of these parameters are not typically varied from their initial values, leaving 34 as standard calibration parameters (table 1). Each calibration parameter is used within a single module, but because output variables from one module can be used as input variables to other modules, calibration parameters may influence several hydrologic process modules. PRMS has more than 200 output variables that represent specific hydrologic responses over time. As a result of model complexity and the extensive set of parameters, sensitivity analyses for PRMS are highly complex and essential for successful model application. During model sensitivity analysis, the influence of calibration parameters on output variables is assessed. During model calibration, calibration parameters are adjusted, and output variables are compared to observed hydrologic data to assess model performance.

For this report, an uncalibrated PRMS model was built of the upper Rio Hondo Basin from the headwaters to approximately 19 mi downstream from the Rio Hondo above Chavez Canyon near Hondo streamgage that included 24 HRUs from the NHM. This model was used for sensitivity analysis to identify the most sensitive calibration parameters for the upper Rio Hondo Basin for an 11-year evaluation period (1990-2000). Then, two calibrated PRMS models were developed for the North Fork Eagle Creek subwatershed: prefire (November 30, 2007, to April 30, 2012) and postfire (October 31, 2013, to December 31, 2015).

\section{Sensitivity Analysis Methods}

\section{Purpose of Sensitivity Analysis}

Selection of the most appropriate calibration parameters is critical to a successful calibration process (Hay and others, 2006). Several important factors should be considered during parameter selection. First, it is important to understand which processes and parameters are most influential on hydrologic model results and how they vary within the watershed. Watershed hydrologic processes, such as infiltration, snowmelt, and overland flow, vary according to spatially and temporally varying combinations of land surface and climatological conditions (Markstrom and others, 2016). For example, streamflow from a cold mountainous watershed may demonstrate a high dependency on snowmelt processes, whereas streamflow from a warmer lowland watershed may demonstrate greater dependency on ET processes. As such, the most influential parameters may also be expected to vary depending on location within the watershed. Second, it is important to know if site-specific data are available to parameterize the model. Distributed hydrologic models typically have a large number of adjustable input parameters in order to allow accurate simulation of hydrologic response for a variety of conditions in different areas, but data sources are not normally available for all parameters (Beven, 2002; Kirchner, 2006). Lastly, it is important to understand how model parameters interact. Because of interactions among parameters, several different combinations of adjustable input parameters, some of which may be unrealistic (that is, "get the right result for the wrong reasons"), may produce similar model performance, a situation known as "equifinality."

An analysis conducted to determine the strength of input-parameter influence on model-output response is called a "sensitivity analysis." Sensitivity analyses are conducted for a specific model and study area to focus model development and calibration efforts on the most influential parameters (Moriasi and others, 2015b; Yuan and others, 2015). Sensitivity analyses can focus model parameterization efforts on the most influential parameters, identify important interactions that may influence calibration strategies, and reduce the potential for unrealistic calibration results through equifinality. 
Table 1. Precipitation-Runoff Modeling System (PRMS) calibration parameters (from Markstrom and others, 2016).

[ET, evapotranspiration]

\begin{tabular}{|c|c|c|c|}
\hline Parameter name & Description & PRMS module & Range \\
\hline adjmix_rain & Factor to adjust rain proportion in a mixed rain/snow event & Climate & $0.6-1.4$ \\
\hline tmax_allrain & Maximum air temperature above which precipitation is rain & Climate & $-8.0-60.0$ \\
\hline tmax_allsnow & Maximum air temperature below which precipitation is snow & Climate & $-10.0-40.0$ \\
\hline dday_intcp & Intercept in degree-day equation & Solar radiation & $-60.0-10.0$ \\
\hline dday_slope & Slope in degree-day equation & Solar radiation & $0.2-0.9$ \\
\hline ppt_rad_adj & Solar radiation adjustment threshold for precipitation days & Solar radiation & $0.0-0.5$ \\
\hline radj_sppt & Solar radiation adjustment on summer precipitation days & Solar radiation & $0.0-1.0$ \\
\hline radj_wppt & Solar radiation adjustment on winter precipitation days & Solar radiation & $0.0-1.0$ \\
\hline radmax & Maximum solar radiation caused by atmospheric effects & Solar radiation & $0.1-1.0$ \\
\hline tmax_index & Temperature to determine precipitation adjustments to solar radiation & Solar radiation & $-10.0-110.0$ \\
\hline jh_coef & Coefficient used in Jensen-Haise potential ET computations & Potential ET & $0.005-0.06$ \\
\hline jh_coef_hru & Coefficient used in Jensen-Haise potential ET computations & Potential ET & $5.0-25.0$ \\
\hline srain_intcp & Summer rain interception storage capacity & Interception & $0.0-1.0$ \\
\hline wrain_intcp & Winter rain interception storage capacity & Interception & $0.0-1.0$ \\
\hline cecn_coef & Convection condensation energy coefficient & Snow & $2.0-10.0$ \\
\hline emis_noppt & Average emissivity of air on days without precipitation & Snow & $0.757-1.0$ \\
\hline freeh2o_cap & Free-water holding capacity of snowpack & Snow & $0.01-0.2$ \\
\hline potet_sublim & Snow sublimation fraction of potential ET & Snow & $0.1-0.75$ \\
\hline carea_max & Maximum area contributing to surface runoff & Surface runoff & $0.0-1.0$ \\
\hline smidx_coef & Nonlinear contributing area coefficient & Surface runoff & $0.001-0.06$ \\
\hline smidx_exp & Exponent in nonlinear contributing area coefficient & Surface runoff & $0.1-0.5$ \\
\hline fastcoef_lin & Linear coefficient in equation to route preferential flow & Soil zone & $0.001-0.8$ \\
\hline fastcoef_sq & Nonlinear coefficient in equation to route preferential flow & Soil zone & $0.001-1.0$ \\
\hline pref_flow_den & Fraction of the soil zone in which preferential flow occurs & Soil zone & $0.0-0.1$ \\
\hline sat_threshold & Water capacity between field capacity and total saturation & Soil zone & $1.0-999.0$ \\
\hline slowcoef_lin & Linear coefficient for interflow routing & Soil zone & $0.001-0.5$ \\
\hline slowcoef_sq & Nonlinear coefficient for interflow routing & Soil zone & $0.001-1.0$ \\
\hline soil2gw_max & Maximum soil-water excess that is routed directly to groundwater & Soil zone & $0.0-0.5$ \\
\hline soil_moist_max & Maximum available water-holding capacity of soil zone & Soil zone & $0.001-10.0$ \\
\hline soil_rechr_max & Maximum available water-holding capacity of recharge zone & Soil zone & $0.001-5.0$ \\
\hline ssr2gw_exp & Nonlinear coefficient in equation used to route soil-zone water to groundwater & Soil zone & $0.0-3.0$ \\
\hline ssr2gw_rate & Linear coefficient in equation used to route soil-zone water to groundwater & Soil zone & $0.05-0.8$ \\
\hline transp_tmax & Temperature that determines start of the transpiration period & Soil zone & $0.0-1000.0$ \\
\hline gwflow_coef & Linear groundwater discharge coefficient & Groundwater & $0.001-0.5$ \\
\hline
\end{tabular}




\section{Fourier Amplitude Sensitivity Test}

A national-level sensitivity analysis was performed by Markstrom and others (2016) to better understand interactions between PRMS calibration parameters and process variables. They used a Fourier amplitude sensitivity test (FAST) procedure to analyze 110,000 subregions, or HRUs, of the coterminous United States for an 11-year evaluation period (1990-2000). The FAST analysis used seven fundamental daily streamflow statistics, where each statistic represented nonredundant information on hydrologic response (Archfield and others, 2014). Analysis in Markstrom and others (2016), as well as in this report, focuses on three of the seven statistics: mean daily flow (representative of total daily flow volume), coefficient of variation of daily flow (CV; representative of flow "flashiness"), and autoregressive lag-1 correlation coefficient of daily flow (AR-1; representative of day-to-day timing of flow).

The sensitivity analysis used by Markstrom and others (2016) focused on eight of the PRMS hydrologic processes: snowmelt, surface runoff, infiltration, soil moisture, ET, interflow, base flow, and streamflow. This sensitivity analysis allowed for a better understanding of key hydrologic processes for an HRU and the dominant parameters that affect each key process to improve runoff modeling within a study area (Markstrom and others, 2016). The FAST results have shown that on average (of 110,000 HRUs in the coterminous United States), 90 percent of the parameter sensitivity to key hydrologic processes in a given HRU comes from just 2 to 9 parameters, which is a small subset of the 35 standard calibration parameters. Using the sensitivity analysis to selectively reduce the number of calibration parameters improves understanding of PRMS process-parameter interactions and reduces the potential for equifinality by reducing the number of parameters needed to be adjusted to make an accurate calibration.

\section{Fourier Amplitude Sensitivity Test Interface}

Because of the size of the FAST output for the coterminous United States, a large amount of data manipulation and analysis is needed to parse and analyze the data for a smaller study area. As part of this study, a platform was created to provide a quasi-graphical user interface to easily query the FAST data by region, HRU, groupings of HRUs, specific aspects of the flow regime, and groupings of flow-regime aspects. The interface also converted the dimensionless quantity outputs from FAST into percentages that represent (a) the amount of influence the calibration parameters have on the processes, and (b) the amount of influence the processes have within the modeling space. The parameters are then ordered in terms of total percent of influence for the study area(s). Similarly, the processes are ordered by influence. This procedure allows quick, sitespecific determination of the key parameters and processes and their associated influence on various aspects of the flow regime, which permits a more informed, quicker calibration process in which only key processes and affiliated parameters are optimized for an area.

\section{Model Calibration Methods}

\section{Purpose of Calibration}

Calibration is a process of adjusting model parameters to improve (optimize) simulation of real-world variables and processes, as indicated by comparison between simulated and observed data. All hydrologic models need to be calibrated to ensure that model results are reasonable and representative for the target study areas, conditions, and time periods. Despite having complex process representations and numerous parameters and variables, hydrologic models remain simplifications of reality. Hydrologic data used for comparison during calibration are limited and uncertain (Harmel and others, 2009); for example, each USGS streamflow discharge measurement is assigned an accuracy ranging from excellent $(<2$ percent error) to poor ( $>8$ percent error) (Sauer and Meyer, 1992). As a result, models are subject to equifinality "because no single (global) optimum parameter set exists when imperfect models are applied to incomplete data” (Zeckoski and others, 2015, p. 1624). The model calibration process should carefully apply multiple qualitative and quantitative assessments to ensure that the resulting set of calibrated parameters is adequately robust for the intended application (Harmel and others, 2014; Daggupati and others, 2015; Saraswat and others, 2015).

\section{Let Us Calibrate Interface}

A graphical user interface, Let Us Calibrate (LUCA), has been developed for building and performing multiobjective, step-wise calibration of hydrologic models, including PRMS, by using a shuffled complex evolution global search algorithm (Hay and Umemoto, 2006; Hay and others, 2007). Model results are compared to observed comparison data for selected variables, such as solar radiation, potential ET, snow-water equivalent, soil moisture, or streamflow. For each comparison dataset, one or more model parameters are adjusted during calibration. Initial values for each parameter are user specified, and LUCA adjusts each parameter within user-specified bounds to optimize a set of user-specified objective functions (such as normalized root-mean-square error [NRMSE] by using daily values, monthly means, or annual means; NashSutcliffe efficiency [NSE]; and others). The individual objective functions are each assigned a weighting $(0-1.0)$ that sum to 1.0 to define their relative contributions to an overall multiobjective function. 
The calibration process includes a user-specified number of (a) steps, where each step simultaneously calibrates a set of parameters by using a specified comparison dataset, and parameters calibrated during each step are used as initial values for subsequent steps; and (b) rounds, where all predefined steps are performed for each round, and parameter values from one round serve as the initial values for subsequent rounds. During each step, the model is run many hundreds or thousands of times, each time with a different combination of values for the parameters selected to be calibrated in that step. Parameter values for the model run that has the best overall multiobjective function are selected and used as initial values for subsequent steps in that round. Different sets of parameters are adjusted and optimized in each step. After completing all the steps in a single round, the process is repeated in the next round with a new set of initial parameter values. Each round recalculates the optimal parameter values in each step, given a different set of initial parameter values from the previous round. In this way, interactions among parameters in different steps are considered.

\section{Performance Measures}

Calibrated model performance was assessed by using graphical and statistical methods, as recommended by Harmel and others (2014, 2018) and Moriasi and others (2007, 2015a). Graphical methods included comparison of simulated and observed streamflow time-series hydrographs and cumulative streamflow distributions. Statistical performance measures were calculated by using means of daily values for the designated time step (annual, monthly, or daily). Statistical measures included mean and standard deviations of simulated and observed values, slope and coefficient of determination $\left(\mathrm{R}^{2}\right)$ for the simulated versus observed regression, mean bias of simulated versus observed values, square root of the mean of squared errors between simulated and observed values (RMSE), ratio of RMSE to standard deviation (RSR), and
NSE relative to the observed mean (Moriasi and others, 2007). Additional model verification was performed to ensure that specific hydrologic processes were reasonable and could be explained on the basis of expected real-world processes.

\section{PRMS Model Sensitivity Analysis for Upper Rio Hondo Basin}

For this study, an uncalibrated PRMS model was built of the upper Rio Hondo Basin from the headwaters to approximately 19 mi downstream from the Rio Hondo above Chavez Canyon near Hondo streamgage (table 2). Twenty-four HRUs that covered the study area watershed were extracted from the NHM along with model input data from the NHM (Viger, 2014; Viger and Bock, 2014). FAST results from Markstrom and others (2016) for an 11-year evaluation period (1990-2000) were assessed for 24 individual HRUs in the upper Rio Hondo Basin.

\section{Sensitivity in Upper Rio Hondo Basin}

The FAST results were analyzed by HRU to determine which of the eight selected hydrologic processes exhibited the greatest influence in simulating three streamflow statistics: mean daily flow (representative of total daily flow volume), CV (representative of flow "flashiness"), and AR-1 (representative of day-to-day timing of flow) (fig. 3). Simulation of mean streamflow was most sensitive to parameters related to snowmelt or infiltration throughout the upper Rio Hondo Basin. Flashiness and timing statistics were most sensitive to interflow in most of the basin's eastern and northern HRUs. In those HRUs of the extreme western basin or higher elevations in general, $\mathrm{CV}$ of streamflow was most sensitive to soil moisture parameters, and AR-1 of streamflow was most sensitive to infiltration and ET parameters.

Table 2. U.S. Geological Survey streamgages in the upper Rio Hondo Basin and descriptions, including drainage area, elevation, and beginning and ending dates of the period of record.

[Streamgage information from U.S. Geological Survey (2018b). mi² $^{2}$ square miles; ft, feet; NGVD 29, National Geodetic Vertical Datum of 1929; POR, period of record; NM, New Mexico; dates are presented in month/day/year format]

\begin{tabular}{|c|c|c|c|c|c|}
\hline $\begin{array}{l}\text { Station } \\
\text { number }\end{array}$ & Streamgage name & $\begin{array}{l}\text { Drainage area } \\
\qquad\left(\mathrm{mi}^{2}\right)\end{array}$ & $\begin{array}{c}\text { Elevation } \\
\text { (ft, NGVD 29) }\end{array}$ & POR begin date & POR end date \\
\hline 08387550 & North Fork Eagle Creek near Alto, NM & 3.16 & 7,900 & 9/6/2007 & $5 / 31 / 2017$ \\
\hline 08387600 & Eagle Creek below South Fork near Alto, NM & 8.14 & 7,600 & 8/27/1969 & $5 / 31 / 2017$ \\
\hline 08390020 & Rio Hondo above Chavez Canyon near Hondo, NM & 588 & 5,160 & $8 / 21 / 2008$ & $5 / 31 / 2017$ \\
\hline
\end{tabular}




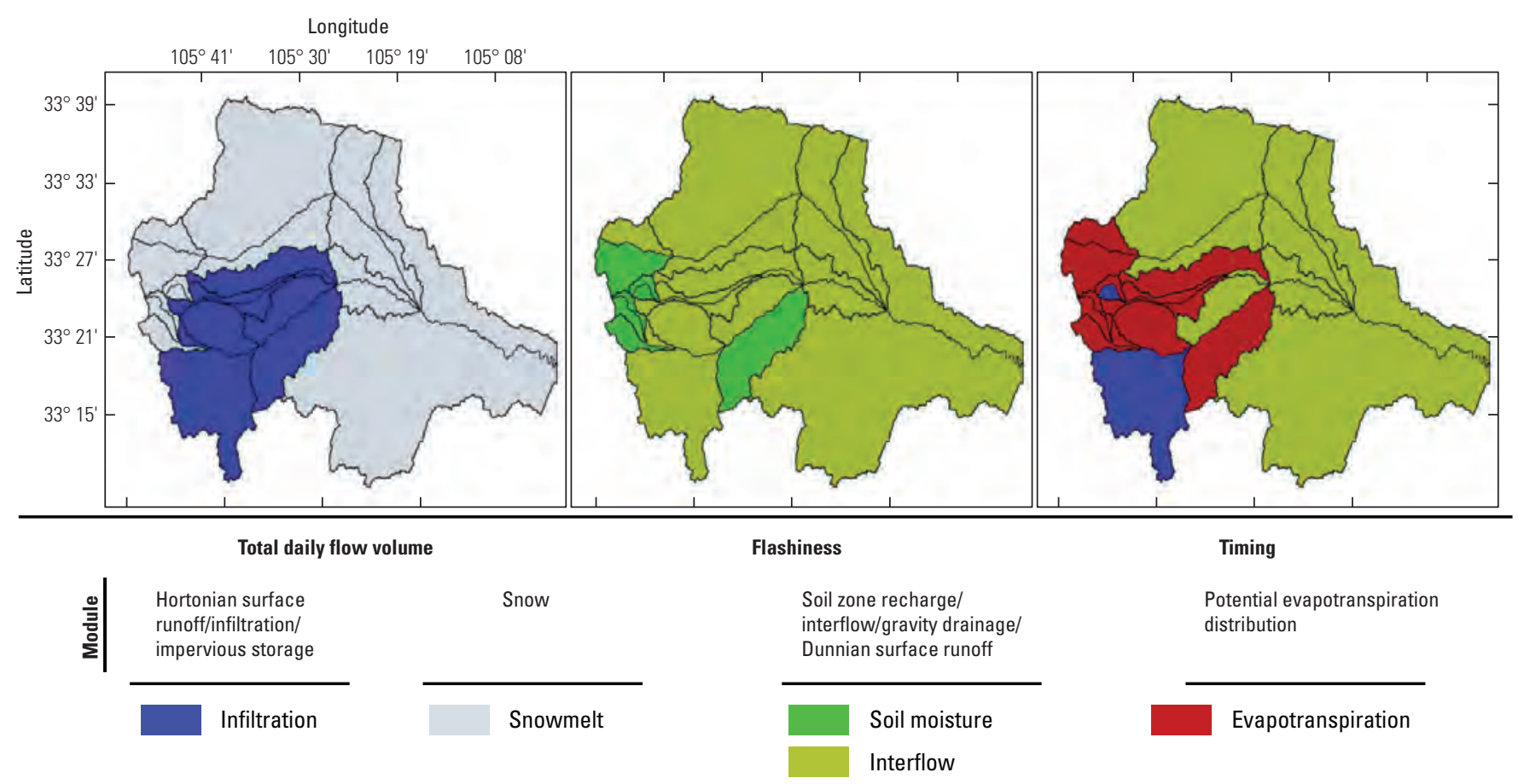

Figure 3. Hydrologic process with greatest sensitivity to each of three streamflow statistics (total daily flow volume [mean daily streamflow], flashiness [coefficient of variation of daily streamflow], and timing [autoregressive lag-1 correlation coefficient of daily streamflow]) by hydrologic response unit (HRU), upper Rio Hondo Basin, New Mexico. Parameter and module descriptions are found in Markstrom and others (2015).

The hydrologic processes that exhibited the greatest overall sensitivity (72 percent) in the basin were interflow, soil moisture, ET, and infiltration (fig. 4). Sensitivity, normalized as a percentage of total influence contributed by each process on each streamflow statistic (total daily volume, flashiness, and timing), varied for each HRU for each of the three streamflow statistics. Overall sensitivity, calculated as an average of the three statistics, was 21 percent for interflow, 20 percent for soil moisture, 18 percent for ET, and 13 percent for infiltration (fig. 4). Although snowmelt was a dominant process for total daily volume, it was not included because data were insufficient to define snowmelt's effects on flashiness and timing.

Contribution to streamflow-response sensitivity from the four dominant hydrologic processes varied widely across the basin, ranging from 10 percent influence to 25 percent influence among HRUs (fig. 4). Levels of sensitivity tended to exhibit similarity among clusters of adjacent HRUs within the basin, indicating similarity in local hydrologic response for adjacent HRUs with similar characteristics. However, sensitivity was not always consistent among streamflow statistics. Specific HRUs that were sensitive to the mean response of a hydrologic process often showed different levels of sensitivity for CV and AR-1 response of the same process. Several HRUs experienced a general trend of increasing sensitivity to interflow and soil moisture going from mean to $\mathrm{CV}$ to AR-1 statistics, indicating that for these HRUs, interflow and soil moisture were more influential for streamflow flashiness and timing than for streamflow volume. However, ET and infiltration did not demonstrate a similar general trend. Specific HRUs in the western basin that demonstrated higher sensitivity to infiltration demonstrated less sensitivity to ET and interflow. Overall, few generalities or trends were visually detected in sensitivity across HRUs, among processes, or among streamflow statistics.

The parameter (from those listed in table 1) with greatest influence on three streamflow statistics from each of four key hydrologic processes varied among HRUs (fig. 5). These results provided greater specificity about parameters that would be influential in model calibration. For example, the climate (temperature and precipitation distribution) module parameter tmax_allsnow was the most sensitive parameter for simulation of interflow mean volume and infiltration CV in most HRUs of the basin. Similarly, the potential ET-module parameter jh_coef was the most sensitive parameter for simulation of infiltration and soil moisture mean volumes in most of the basin and for simulation of ET and soil moisture CVs in all HRUs. The soil-zone module fastcoef_lin parameter had greatest influence on CV and AR-1 for interflow throughout most of the HRUs in the basin. Parameters that showed dominant sensitivity for large numbers of HRUs would be important to include in model calibration. 


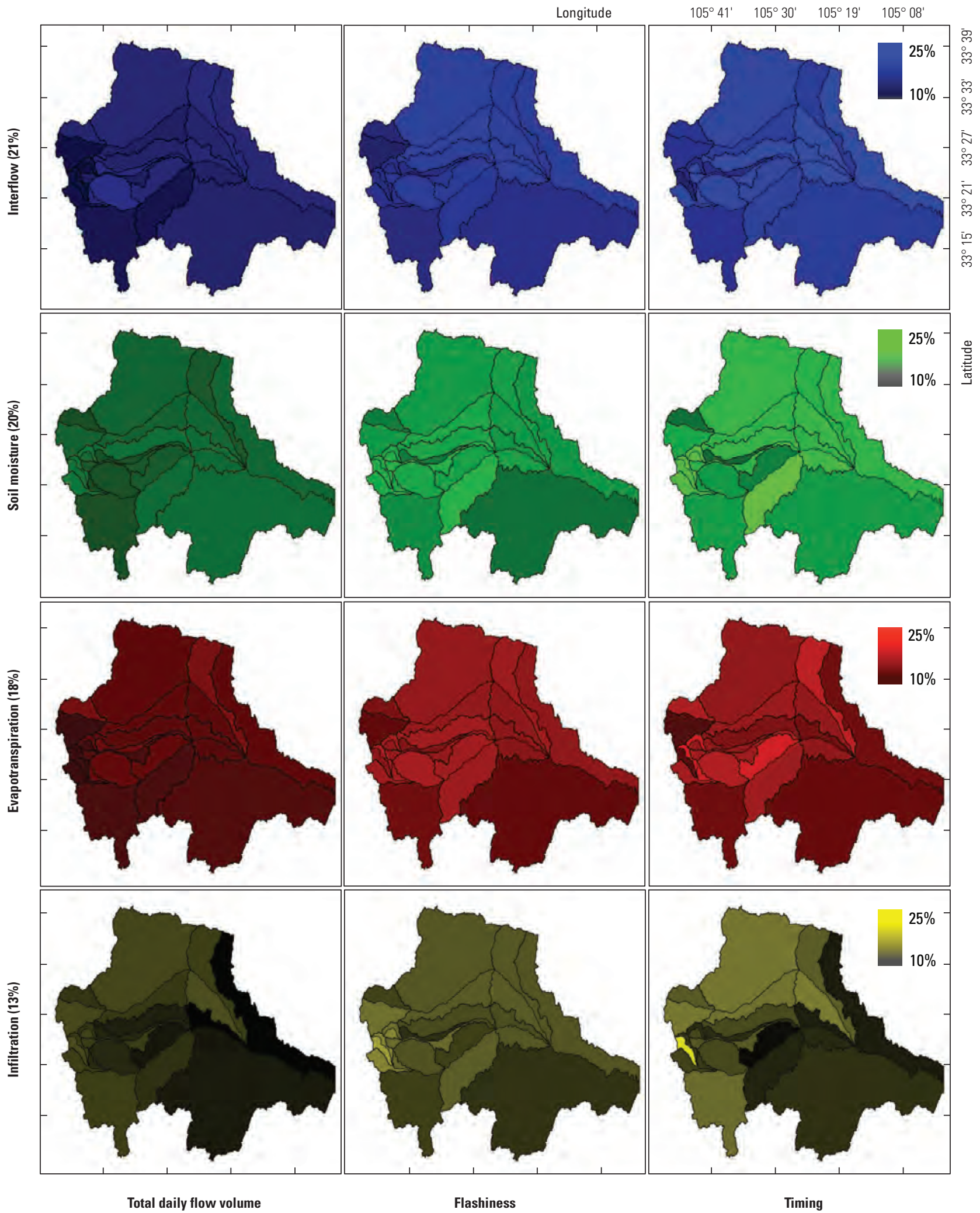

Figure 4. Normalized process sensitivity for three streamflow statistics (total daily flow volume [mean daily streamflow], flashiness [coefficient of variation of daily streamflow], and timing [autoregressive lag-1 correlation coefficient of daily streamflow]) by hydrologic response unit, upper Rio Hondo Basin, New Mexico. Overall sensitivity, calculated as an average of the three statistics, is given in percentages on the $y$-axis. Contribution to streamflowresponse sensitivity from the four dominant hydrologic processes range from lower influences in darker shades to higher influences in lighter shades. 


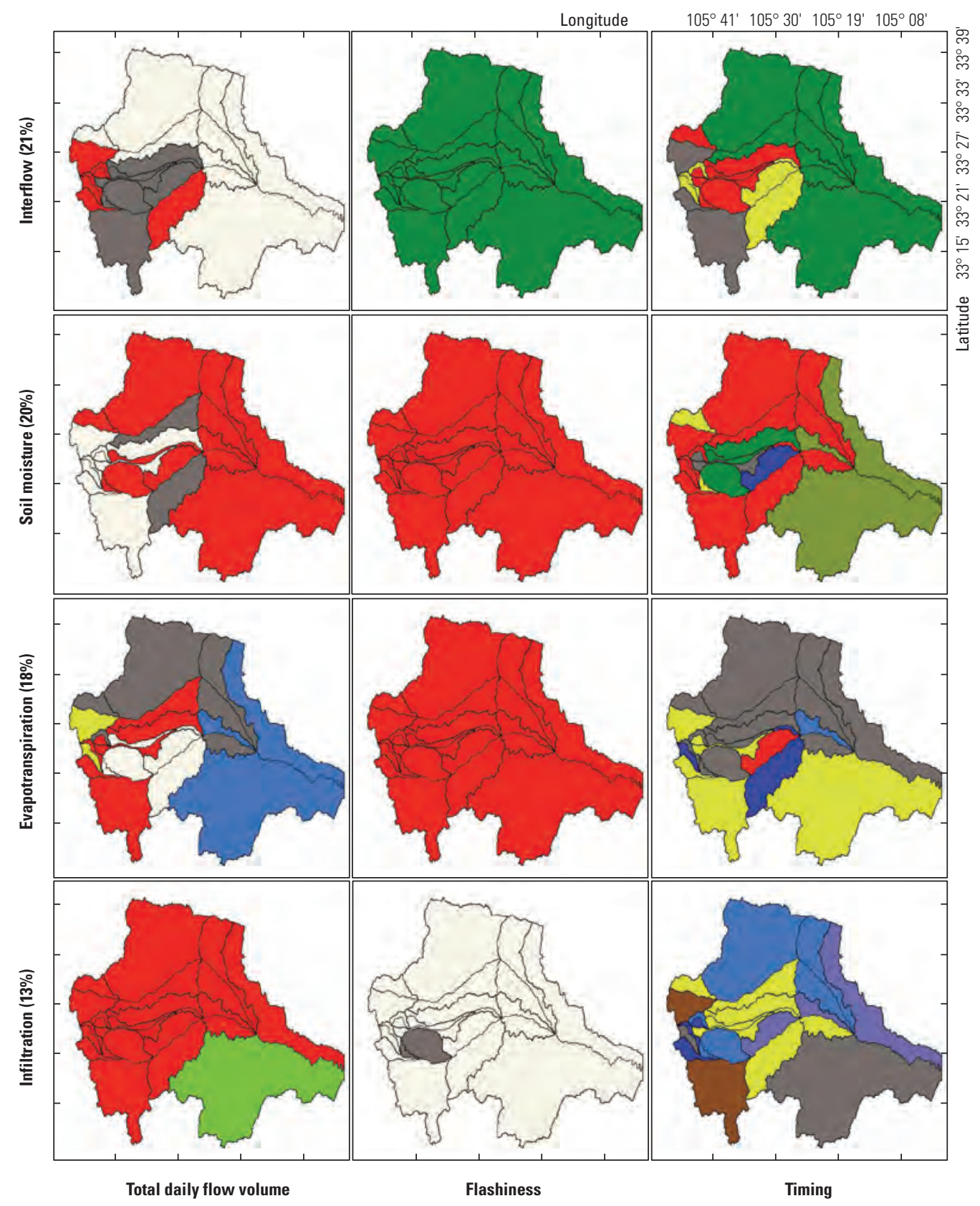

EXPLANATION

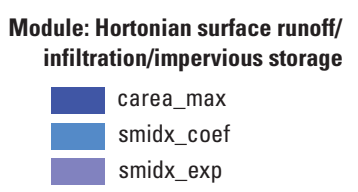

Module: potential ET distribution jh_coef

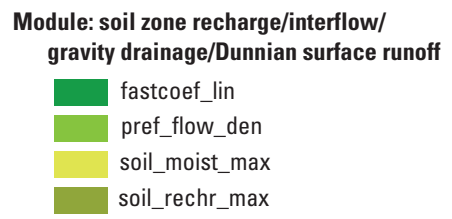

Module: soil zone recharge/interflow/ gravity drainage/Dunnian surface runoff

fastcoef_lin

pref_flow_den

soil_moist_max

soil_rechr_max

Module: interception

srain_intcp
Module: groundwater flow
gwflow_coef
Module: Climate, air temperature and precipitation distribution $\square$ tmax_allsnow

Figure 5. Normalized process sensitivity for three streamflow statistics (total daily flow volume [mean daily streamflow], flashiness [coefficient of variation of daily streamflow], and timing [autoregressive lag-1 correlation coefficient of daily streamflow]) by hydrologic response unit and model parameter, upper Rio Hondo Basin, New Mexico. Overall sensitivity, calculated as an average of the three statistics, is given in parentheses on the $y$-axis. Parameter and module descriptions are found in Markstrom and others (2015). 


\section{Sensitivity in the North Fork Eagle Creek Subwatershed}

The North Fork Eagle Creek subwatershed HRUs (HRUs 487 and 490, fig. 2) showed greatest sensitivity to snowmelt for total volume, soil moisture for streamflow flashiness, and infiltration (HRU 487) and ET (HRU 490) for streamflow timing (figs. 3, 4). Simulation of total volume was most influenced by jh_coef (potential ET module) for the processes of interflow (both HRUs), infiltration (both HRUs), and ET (HRU 487), and by tmax_allsnow (climate [temperature and precipitation distribution] module) for the soil moisture process (fig. 5). Simulation of streamflow flashiness was most influenced by fastcoef_lin (soil-zone module) for the interflow process, jh_coef (potential ET module) for the soil moisture and ET processes, and tmax_allsnow (climate [temperature and precipitation] distribution module) for the infiltration process (fig. 5). Streamflow timing was most influenced by soil_moist_max (soil-zone module), jh_coef (potential ET module), srain_intcp (interception module), and smidx_coef and carea_max (surface runoff module) parameters (fig. 5).

\section{PRMS Model Calibration for the North Fork Eagle Creek Subwatershed}

The PRMS model developed from the sensitivity analysis was adapted for use in calibration. The upper Rio Hondo Basin has a large number of reservoirs and irrigation canals, all of which alter natural streamflow in the basin. Bonito Lake (1,500-acre-foot [acre-ft] capacity) along Rio Bonito, Mescalero Lake (3,000-acre-ft capacity) on the Mescalero
Apache Indian Reservation, and a reservoir commonly known as Grindstone Lake (1,520-acre-ft capacity) west of the town of Ruidoso and fed by surface water diverted from Rio Ruidoso are three of six constructed lakes in the basin. These reservoirs and diversions alter natural streamflows and complicate calibration of rainfall-runoff models. In addition, modeling efforts were focused on HRUs that were entirely within fire-affected areas and above existing streamflow gage(s) with period(s) of record before and after the 2012 Little Bear Fire.

Available USGS streamgages (fig. 1) in the fire-affected area (fig. 2) include North Fork (08387550) and South Fork (08387575) Eagle Creek near Alto, N. Mex., both with periods of record since September 2007, and Eagle Creek below South Fork near Alto, N. Mex. (08387600), with period of record since August 1969 (table 2). The North Fork Eagle Creek subwatershed was selected for calibration for several reasons: (1) the North Fork subwatershed is coincident with two HRUs (HRUs 490 and 487, fig. 2) in the NHM upper Rio Hondo Basin PRMS model, (2) both HRUs are entirely within the fire-affected area (fig. 2), (3) the South Fork subwatershed contains a reservoir, managed by the Apache Tribe, that can artificially affect streamflows, and (4) available USGS streamgages (table 2) allow for the construction of a daily timeseries of discharge for the North Fork subwatershed. The North Fork streamgage is located more than 1 mi upstream from the confluence of the North Fork and South Fork into Eagle Creek; however, the South Fork and Eagle Creek streamgages are within $300 \mathrm{ft}$ of each other, just upstream and downstream from the confluence. This proximity allowed a daily timeseries of discharge for the North Fork to be constructed by subtraction of the South Fork streamgage data from the Eagle Creek streamgage data (fig. 6).

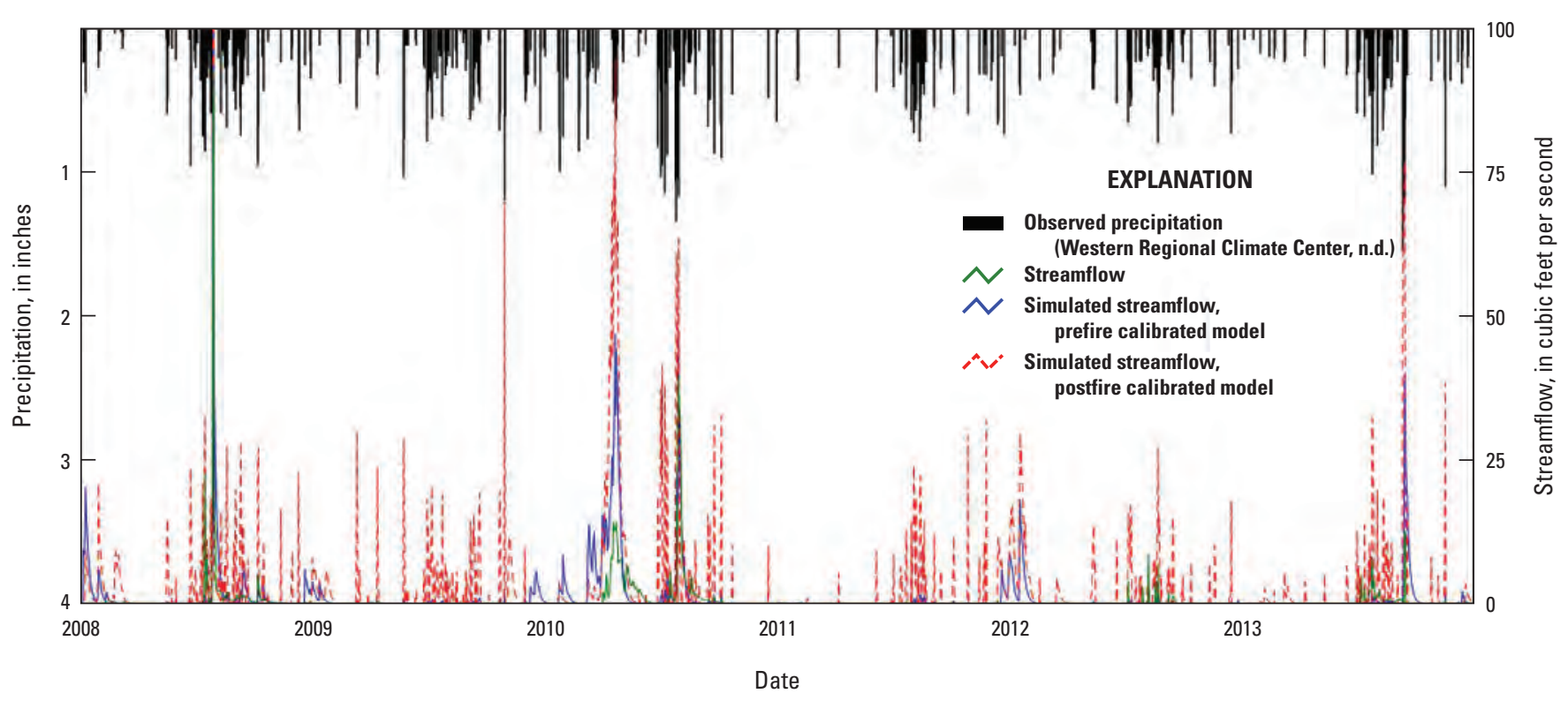

Figure 6. Daily simulated (prefire and postfire calibrated models) and observed streamflow and precipitation for the study period (2008-14) for the North Fork Eagle Creek subwatershed, New Mexico. 
In order to use the same PRMS model framework that was used for the sensitivity analysis directly, daily precipitation input data for all HRUs except the two North Fork HRUs were set to zero, which forced daily streamflow to represent only outflow from North Fork Eagle Creek. Initial input parameters for the North Fork Eagle Creek HRUs were adopted from the Geospatial Fabric for the NHM (Viger, 2014; Viger and Bock, 2014; Regan and others, 2018) except as modified by using specific baseline values or as adjusted during calibration. The NHM Geospatial Fabric soil parameters were derived from the Soil Survey Geographic database (Natural Resources Conservation Service, U.S. Department of Agriculture, 2012). Geospatial Fabric landcover parameters were derived from the 2001 National Land Cover Database (Homer and others, 2007). Geospatial Fabric subsurface flux parameters were derived from the map products of Gleeson and others (2011).

Calibration of PRMS was conducted only for the May through October period in this study for two reasons. The North Fork Eagle Creek and stream reaches at the Eagle Creek streamgages typically freeze each winter. Streamflow measurement during ice cover can be problematic because ice cover alters the relation between stream stage and discharge that is used to develop streamflow hydrographs at many USGS streamgages (Turnipseed and Sauer, 2010), including Eagle Creek. As a result, discharge often is not measured during part or all of the winter period, resulting in data gaps in daily discharge records. Second, a primary goal of this study was to characterize postfire streamflow conditions during higher flow conditions that may cause flooding and associated health and safety concerns important to the NMDHSEM. A majority of precipitation (59 percent of annual precipitation for the 19422013 period of record) occurs in the summer months (June to September) from monsoon storms (Sherson and Rice, 2015). As a result, higher streamflow events that are a focus of this study typically occur because of these monsoonal convective storms during the summer to early fall period.

\section{Meteorological Data}

Daily precipitation, minimum daily temperature, and maximum daily temperature data for the study period (2007-15) were obtained from the Daymet: Daily Surface Weather Data on a 0.62-mi Grid for North America, Version 3 (Thornton and others, 2016). Daymet is a collection of 0.62-mi gridded estimates of precipitation, temperature, and solar radiation derived by interpolation and extrapolation from observation data (Thornton and others, 2016) and a digital elevation model. These data were used for the calibration of the prefire and postfire models to the constructed, observed hydrograph for North Fork Eagle Creek.

A gridded precipitation dataset that represents the spatial heterogeneity of precipitation over a landscape is superior to precipitation data from a singular point (for example, a weather station) for the purpose of simulating spatially distributed landscape processes by using a watershed model. However, it is possible that gridded data, which reflect integrated and interpolated meteorological data over large areas, may dampen signals of extreme events, including heterogeneous, localized monsoonal storms. Monsoonal-storm signal dampening may subsequently reduce the modeled hydrologic signal of fire-affected watersheds. As such, summer precipitation from one precipitation gage at a similar latitude and elevation band was used as meteorological forcing to the prefire and postfire calibrated models rather than Daymetbased precipitation. Although precipitation gage data from a site outside the subwatershed may not provide the best data for comparing simulated streamflow to the actual streamflow signal, it would be superior for comparing potential hydrologic effects of various summer precipitation regimes within the subwatershed for prefire and postfire conditions.

Daily precipitation from the Cloudcroft, N. Mex., gage (site 291931) from the National Weather Service Cooperative Network (Western Regional Climate Center) was used as the precipitation input to the calibrated pre- and postfire models. The precipitation gage is located at an elevation of $8,660 \mathrm{ft}$ (mean elevation of North Fork Eagle Creek is 8,500 ft), $30.9 \mathrm{mi}$ south of the centroid of the North Fork Eagle Creek subwatershed (fig. 1), and has a period of record of approximately 29 years (Western Regional Climate Center).

\section{Baseline Prefire Parameter Adjustments}

Eight calibration parameters (covden_sum, covden_win, snow_intcp, srain_intcp, wrain_intcp, rad_trnc, soil_rechr_ max, and soil_moist_max) were adjusted to user-specified baseline values prior to calibration and were not included in the automated calibration (table 3). In the interception module, covden_sum and covden_win were based on the USGS LANDFIRE database (Ryan and Opperman, 2013) of existing vegetation cover for fire-affected Eagle Creek HRUs in 2010 for prefire conditions and in 2014 for postfire conditions (U.S. Geological Survey, 2013). The vegetation density within the LANDFIRE database represents live canopy cover for a 98-ft (30-meter) grid cell by using the stem-map model from Toney and others (2009) and is informed from satellite imagery and extensive field-referenced data. Four parameters (srain_intcp, wrain_intcp, rad_trnc, and snow_intcp) are directly related to canopy density in PRMS and should also be manipulated if canopy density is manually changed. In order to establish reasonable values for these parameters, four basic linear regression equations (eqs. 1-4a) were created by using HRUbased parameter and canopy-density values initially derived from the NHM Geospatial Fabric:

srain_intcp $=0.01293[$ covden_xxx $]+0.039883, R^{2}=0.57$ (1)

wrain_intcp $=0.012244$ [covden_xxx] $+0.039883, \mathrm{R}^{2}=0.54(2)$ 
rad_trnc $=1.0652\left[\right.$ covden_xxx] $+0.86557, \mathrm{R}^{2}=0.94$

snow_intcp $=0.07$ [covden_xxx] $+0.0417, \mathrm{R}^{2}=0.93$

where covden_xxx is either covden_sum or covden_win, depending on the month. Despite a good fit $\left(\mathrm{R}^{2}=0.93\right)$, the adjusted values for snow_intcp were very low, with a maximum of less than 0.039 in., which is unrealistic. The snow_intcp equation slope was increased by an order of magnitude (eq. 4b) to give maximum capable wrain_intcp (within PRMS), which was still very low according to prior studies (Moeser and others, 2015a,b, 2016).

$$
\text { snow_intcp }=0.7[\text { covden_xxx }]+0.0417
$$

Two parameters were manipulated in accordance with Konrad (2004): soil_rechr_max was changed postfire to 0.5 , and soil_ moist_max was changed postfire to 1.5 .

\section{Prefire Model Calibration}

The PRMS prefire model was run for the entire period of Daymet gridded meteorological data record (October 1, 2007, to December 31, 2015), and results from the prefire period (November 30, 2007, to April 30, 2012) were used for calibration. Because only discharge data from the May through October period each year were used for calibration, the 7-month precalibration period from October 1, 2007, to April 30, 2008, was used for model initialization. Calibration was conducted by using LUCA following a two-step process (and three rounds), with user-specified parameters as described in table 4. Prefire model statistical performance after calibration is summarized in table 5 .

Overall, the prefire model was considered to be satisfactory. The calibrated model performance in simulating monthly prefire streamflow for the May through October period was assessed as satisfactory based on statistical measures of $\mathrm{R}^{2}(0.74)$ and NSE (0.62), on the basis of watershed-scale model evaluation criteria proposed by Moriasi and others (2015a). RSR (0.61) was assessed as satisfactory by earlier criteria by Moriasi and others (2007). Although mean bias (0.35) was high and considered not satisfactory according to the criteria by Moriasi and others (2015a), slope of the observed versus simulated regression line was nearly 1:1 (1.07), which supports the conclusion of satisfactory performance.

Prefire calibrated model results were comparable to other PRMS studies in watersheds that were largely unaffected by fire. Yazzie and Chang (2017) reported calibrated NSE of 0.73 and bias of 3.5 percent in a PRMS study in a forested basin in Oregon. Hay and others (2006) reported calibrated-model NSE ranged from 0.6 to 0.9 in a mountainous $552-\mathrm{mi}^{2}$ basin in Colorado.

It is important to stress that the prefire (and postfire) model calibration was performed only for the May to October period and should be expected to capture watershed and rainfall-runoff characteristics only during that period. Results should capture the streamflow characteristics of monsoonal storms but may not adequately represent the characteristics of snowmelt runoff in the study area.

\section{Postfire Model Calibration}

The PRMS postfire model was run for the entire period of Daymet gridded meteorological data record (October 1, 2007, to December 31, 2015), and results from the postfire period (October 31, 2013, to December 31, 2015) were used for calibration. Because only discharge data from the May through October period each year were used for calibration, the 71/2-year precalibration period from October 1, 2007, to April 30, 2014, was used for model initialization. Calibration was conducted by using LUCA following a 2-step process, with user-specified parameters as described in table 6 . Postfire model statistical performance after calibration is summarized in table 5.

Overall, the postfire model was considered to be satisfactory to good. The calibrated model performance in simulating monthly postfire streamflow for the May through October period was assessed as satisfactory based on statistical measures of $\mathrm{R}^{2}(0.62)$ and NSE (0.62) and good based on mean bias (0.09), according to watershed-scale model evaluation criteria proposed by Moriasi and others (2015a). RSR (0.6) was assessed as good by earlier criteria from Moriasi and others (2007). Slope of the observed versus simulated regression line (0.76) indicated an increasing underestimation bias as streamflow increased. No studies were found that calibrated the PRMS model for postfire watershed conditions.

\section{Postfire Parameter Adjustments}

Two studies used PRMS to simulate the hydrologic effects of fire but without calibration of the resulting parameters. Konrad (2004) and Yazzie and Chang (2017) determined that the following five parameters should be modified to represent the effects of fire on forest cover by using PRMS: covden_sum, covden_win, rad_trnc, soil_rechr_ max, and soil_moist_max (table 7). Konrad (2004) developed "plausible changes" to these values but did not document the source used to justify the changes or test the resulting postfire model performance after applying these changes. Yazzie and Chang (2017) adapted the method of Konrad (2004) to assign postfire PRMS parameters but also did not provide justification or verification of model parameters.

In this study, selection of baseline values (postfire values in table 3) for each of the identified five parameters was supported by the literature (Konrad, 2004; Yazzie and Chang, 2017). Although the individual values were not adjusted during calibration, the applicability of the values, together with the other calibration parameters (table 6), was confirmed by the postfire calibrated model performance (table 5). 
Table 3. Model baseline parameters adjusted manually prior to calibration (manual calibration values) and calibrated parameters adjusted using the Let Us Calibrate (LUCA) algorithm (automated calibration values) for prefire (November 30, 2007 to April 30, 2012) and postfire (October 31, 2013 to December 31, 2015) simulations in the North Fork Eagle Creek subwatershed. Values are presented as actual values for each of the two HRUs in the subwatershed (HRU487/HRU490) or a range of monthly values (minimum-maximum).

[PRMS, Precipitation-Runoff Modeling System; ET, evapotranspiration; in., inch; sub., sublimation; HRU, hydrologic response unit; coef., coefficient; precip., precipitation; temp., temperature; max., maximum; dist., distribution; ${ }^{\circ} \mathrm{F}$, degrees Fahrenheit]

\begin{tabular}{|c|c|c|c|c|c|}
\hline Parameter & Description & PRMS module & Initial & Prefire & Postfire \\
\hline \multicolumn{6}{|c|}{ Manual calibration values } \\
\hline covden_sum & Canopy density in summer (fraction) & Interception & $0.74 / 0.73$ & $0.75 / 0.75$ & $0.25 / 0.25$ \\
\hline covden_win & Canopy density in winter (fraction) & Interception & $0.72 / 0.68$ & $0.75 / 0.75$ & $0.25 / 0.25$ \\
\hline snow_intcp & $\begin{array}{l}\text { Snow interception storage capacity } \\
\text { (in.) }\end{array}$ & Interception & $0.098 / 0.093$ & $0.90 / 0.90$ & $0.33 / 0.33$ \\
\hline srain_intcp & Rain interception in summer (in.) & Interception & $0.05 / 0.05$ & $0.059 / 0.059$ & $0.042 / 0.042$ \\
\hline wrain_intcp & Rain interception in winter (in.) & Interception & $0.049 / 0.048$ & $0.049 / 0.048$ & $0.043 / 0.043$ \\
\hline rad_trnc & $\begin{array}{l}\text { Transmission coef. for shortwave } \\
\text { radiation through canopy }\end{array}$ & ET/sub. & $0.132 / 0.135$ & $0.129 / 0.569$ & $0.569 / 0.569$ \\
\hline soil_rechr_max & Max. storage in soil recharge zone (in.) & Soil-zone storage & $1.89 / 1.84$ & $1.89 / 1.84$ & $0.5 / 0.5$ \\
\hline soil_moist_max & $\begin{array}{l}\text { Max. available water-holding capacity } \\
\text { of capillary reservoir (in.) }\end{array}$ & Soil-zone storage & $3.11 / 2.99$ & $3.19 / 3.07$ & $1.5 / 1.5$ \\
\hline \multicolumn{6}{|c|}{ Automated calibration values } \\
\hline potet_sublim & $\begin{array}{l}\text { Fraction of potential ET that is } \\
\text { sublimated from snow in canopy }\end{array}$ & ET/sub. & 0.5 & 0.43 & 0.56 \\
\hline gwflow_coef & $\begin{array}{l}\text { Linear coef. to compute groundwater } \\
\text { discharge }\end{array}$ & Groundwater flow & $0.0238 / 0.0250$ & $0.264 / 0.265$ & $0.277 / 0.279$ \\
\hline smidx_coef & $\begin{array}{l}\text { Coef. in nonlinear contributing areas } \\
\text { algorithm per HRU }\end{array}$ & Hortonian runoff & $0.01 / 0.01$ & $0.0048 / 0.0048$ & $0.249 / 0.249$ \\
\hline Jh_coef & $\begin{array}{l}\text { Monthly temp. coef. used in Jensen- } \\
\text { Haise potential ET calculation }\end{array}$ & Potential ET dist. & $0.005-0.026$ & $0.011-0.032$ & $0.024-0.045$ \\
\hline rain_cbh_adj & $\begin{array}{l}\text { Monthly adjustment factor for } \\
\text { measured precip. /per HRU }\end{array}$ & Precip. dist. & $1-1$ & $0.77-0.77$ & $0.72-0.72$ \\
\hline tmax_allrain & $\begin{array}{l}\text { Monthly max. air temp. when precip. } \\
\text { is assumed to be liquid }\left({ }^{\circ} \mathrm{F}\right)\end{array}$ & Precip. dist. & $32-32$ & $35.34-35.34$ & $48.20-48.20$ \\
\hline tmax_allsnow & $\begin{array}{l}\text { Max. air temp. when precip. is } \\
\text { assumed to be solid }\left({ }^{\circ} \mathrm{F}\right)\end{array}$ & Precip. dist. & 32 & 30.3 & 33.1 \\
\hline adjmix_rain & $\begin{array}{l}\text { Monthly factor to adjust rain amount in } \\
\text { a mixed rain/snow event }\end{array}$ & Precip. dist. & $1-1$ & $1.096-1.096$ & $1.142-1.142$ \\
\hline snow_cbh_adj & $\begin{array}{l}\text { Monthly adjustment factor for } \\
\text { measured precip. /per HRU }\end{array}$ & Precip. dist. & $1-1$ & $1.38-1.38$ & $1.95-1.95$ \\
\hline cecn_coef & $\begin{array}{l}\text { Monthly convection condensation } \\
\text { energy coef. }\end{array}$ & Snow & $5-5$ & $4.374-4.374$ & $9.595-9.595$ \\
\hline emis_noppt & $\begin{array}{l}\text { Average emissivity of air on days } \\
\text { without precip. (fraction) }\end{array}$ & Snow & 0.757 & 0.815 & 0.921 \\
\hline freeh2o_cap & Free-water holding capacity of snow & Snow & 0.05 & 0.09 & 0.156 \\
\hline fastcoef_lin & $\begin{array}{l}\text { Linear coef. to route preferential-flow } \\
\text { storage }\end{array}$ & Soil zone storage & $0.011 / 0.010$ & $0.1966 / 0.1964$ & $0.3779 / 0.3777$ \\
\hline dday_intcp & $\begin{array}{l}\text { Monthly intercept in degree-day } \\
\text { equation }\end{array}$ & Solar radiation & $-30--10$ & $-50.7--41.07$ & $-36.62--19.92$ \\
\hline radmax & $\begin{array}{l}\text { Max. fraction of solar radiation that } \\
\text { can reach ground }\end{array}$ & Solar radiation & 0.8 & 0.47 & 0.5 \\
\hline
\end{tabular}


Table 4. User-specified Let Us Calibrate (LUCA) parameters for prefire (November 30, 2007 to April 30, 2012) calibration run in the North Fork Eagle Creek subwatershed, New Mexico.

[NRMSE, normalized root-mean-square error; ${ }^{\circ} \mathrm{F}$, degrees Fahrenheit; ${ }^{\circ} \mathrm{C}$, degrees Celsius; $>$, greater than]

\begin{tabular}{|c|c|c|c|c|c|}
\hline Dataset & $\begin{array}{l}\text { Objective } \\
\text { function }\end{array}$ & Parameter & Parameter range & Parameter units & Calibration \\
\hline \multicolumn{6}{|c|}{ Prefire calibration step 1: Streamflow volume (November 30, 2007-April 30, 2012) } \\
\hline \multirow{3}{*}{$\begin{array}{l}\text { Annual mean (weight: } 0.333 \text { ) } \\
\text { Mean monthly (weight: 0.333) } \\
\text { Monthly mean (weight: } 0.333 \text { ) }\end{array}$} & \multirow{3}{*}{ NRMSE } & rain_cbh_adj & $0.5-2.0$ & Decimal fraction & Mean \\
\hline & & snow_cbh_adj & $0.5-2.0$ & Decimal fraction & Mean \\
\hline & & tmax_allsnow & $28-36$ & $\mathrm{~F}^{\circ}$ & Mean \\
\hline \multicolumn{6}{|c|}{ Prefire calibration step 2: Streamflow timing (November 30, 2007-April 30, 2012) } \\
\hline \multirow{9}{*}{$\begin{array}{l}\text { Daily (weight: } 0.7 \text { ) } \\
\text { Monthly mean (weight: 0.3) }\end{array}$} & \multirow[t]{9}{*}{ NRMSE } & adjmix_rain & $0.6-1.4$ & Decimal fraction & Mean \\
\hline & & cecn_coef & $2.0-10.0$ & Calories per ${ }^{\circ} \mathrm{C}>0$ & Mean \\
\hline & & freeh2o_cap & $0.01-0.20$ & Decimal fraction & Mean \\
\hline & & fastcoef_lin & $0.0001-0.5$ & Decimal fraction & Mean \\
\hline & & gwflow_coef & $0.01-0.3$ & Fraction/day & Mean \\
\hline & & potet_sublim & $0.1-0.75$ & Decimal fraction & Mean \\
\hline & & radmax & $0.1-1.0$ & Decimal fraction & Mean \\
\hline & & srain_intcp & $0.01-0.6$ & Inches & Mean \\
\hline & & soil_moistmax & $0.2-10$ & Inches & Mean \\
\hline
\end{tabular}

Table 5. Model performance measures for initial (uncalibrated) parameters and calibrated parameters at the monthly time-step (mean of daily values) for prefire (November 30, 2007 to April 30, 2012) and postfire (October 31, 2013 to December 31, 2015) streamflow during summer-fall (May through October) in the North Fork Eagle Creek subwatershed.

$\left[\mathrm{ft}^{3} / \mathrm{s}\right.$, cubic feet per second; Stdev, standard deviation; $\mathrm{R}^{2}$, coefficient of determination; RMSE, root-mean-square error; RSR, ratio of RMSE to Stdev; NSE, Nash-Sutcliffe model efficiency]

\begin{tabular}{|c|c|c|c|c|c|c|}
\hline \multirow{2}{*}{ Parameter } & \multicolumn{3}{|c|}{ Prefire } & \multicolumn{3}{|c|}{ Postfire } \\
\hline & Observed & Initial & Calibrated & Observed & Initial & Calibrated \\
\hline Mean $\left(\mathrm{ft}^{3} / \mathrm{s}\right)$ & 0.99 & 16.61 & 1.34 & 3.69 & 1.5 & 3.78 \\
\hline Slope & & 1.41 & 1.07 & & 0.29 & 0.76 \\
\hline $\mathrm{R}^{2}$ & & 0.002 & 0.74 & & 0.37 & 0.62 \\
\hline RSR & & 32.3 & 0.61 & & 0.94 & 0.6 \\
\hline Bias & & 15.62 & 0.35 & & -2.19 & 0.09 \\
\hline NSE & & $-1,085.9$ & 0.62 & & 0.05 & 0.62 \\
\hline
\end{tabular}


Table 6. User-specified Let Us Calibrate (LUCA) parameters for postfire (October 31, 2013 to December 31, 2015) calibration run in the North Fork Eagle Creek subwatershed.

[NRMSE, normalized root-mean-square error; ${ }^{\circ} \mathrm{F}$, degrees Fahrenheit; ${ }^{\circ} \mathrm{C}$, degrees Celsius; >, greater than]

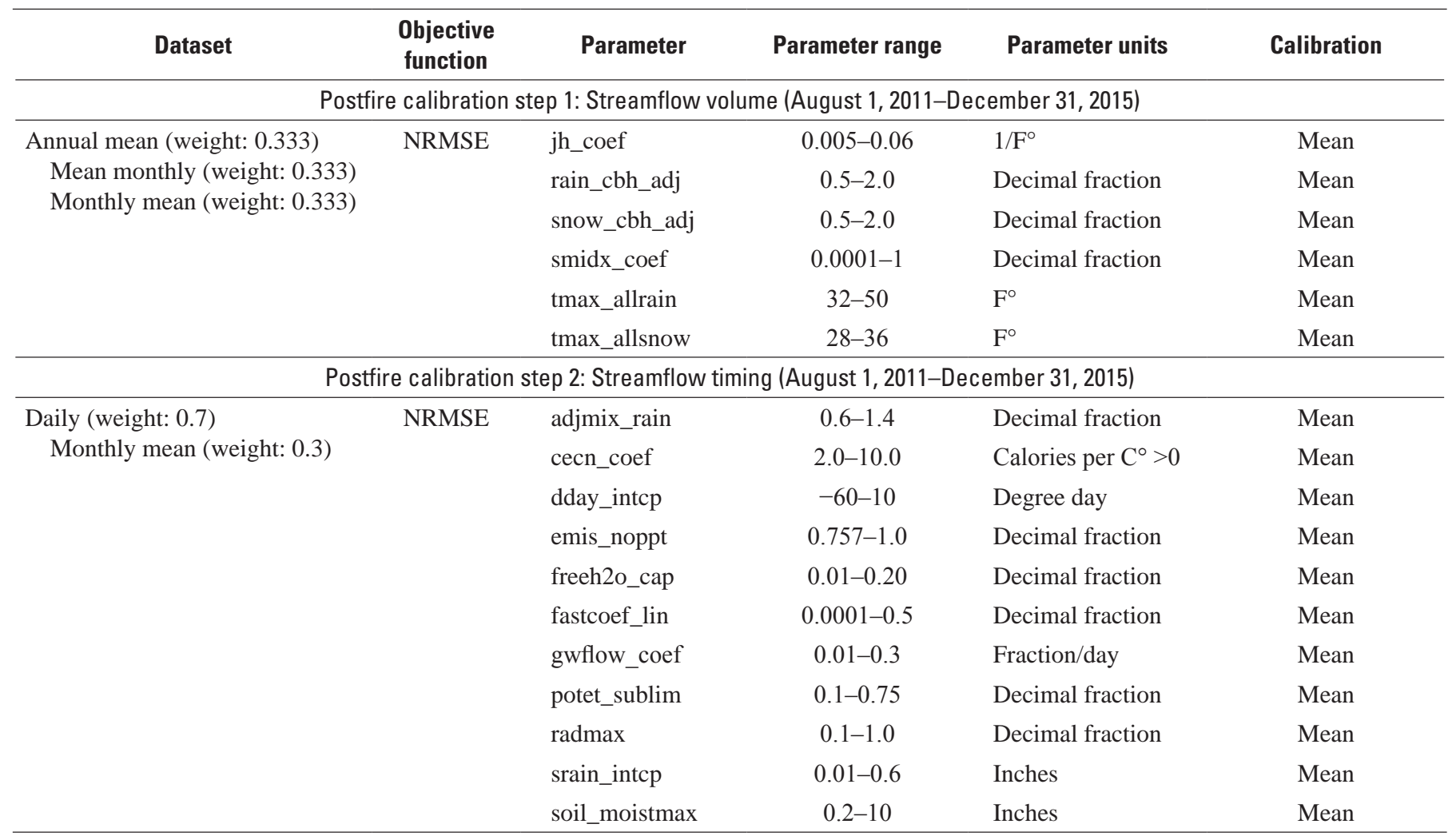

Table 7. Initial and assigned model parameter values to represent changes in forest cover after fire.

[HRU, hydrologic response unit]

\begin{tabular}{|c|c|c|c|c|c|c|}
\hline \multirow{2}{*}{ Parameter } & \multirow{2}{*}{ Description } & \multirow{2}{*}{$\begin{array}{l}\text { This study } \\
\text { Assigned }\end{array}$} & \multicolumn{2}{|c|}{ Konrad (2004) } & \multicolumn{2}{|c|}{ Yazzie and Chang (2017) } \\
\hline & & & Initial & Assigned & Initial & Assigned \\
\hline covden_sum & $\begin{array}{l}\text { Fraction of HRU area covered by } \\
\text { dominant vegetation in summer }\end{array}$ & 0.25 & $0.482-1.0$ & 0.1 & 0.5 & 0.1 \\
\hline covden_win & $\begin{array}{l}\text { Fraction of HRU area covered by } \\
\text { dominant vegetation in winter }\end{array}$ & 0.25 & $0.349-1.0$ & 0.1 & 0.5 & 0.1 \\
\hline rad_trnc & $\begin{array}{l}\text { Fraction of shortwave radiation } \\
\text { transmitted through canopy }\end{array}$ & 0.569 & $0.063-0.448$ & 0.75 & 0.3 & 0.5 \\
\hline soil_rechr_max & $\begin{array}{l}\text { Upper soil storage capacity, in } \\
\text { inches, over HRU area }\end{array}$ & 0.5 & $1.69-1.75$ & 0.5 & 1.643 & 0.55 \\
\hline
\end{tabular}




\section{Discussion and Application of Prefire and Postfire Models}

Statistical measures of watershed model performance indicated that both prefire and postfire PRMS models met satisfactory evaluation criteria. Assessment of graphical results provided further confirmation of model performance as well as insights into prefire and postfire hydrologic processes. For the application portion of this study, data from a single precipitation station (Cloudcroft, N. Mex.) were input into the prefire and postfire models instead of the gridded precipitation data that were used for calibration. Measured precipitation gage data included larger precipitation events, which tend to be attenuated in gridded interpolation methods. Inclusion of these extreme events (including monsoonal storm events that are normal in this area) allowed better representation of the prefire and postfire effects of extreme storm events, which were a particular concern for their effects on flood hazard during postfire conditions. For this reason, use of point precipitation data was expected to better represent the nonlinear hydrologic responses to extreme storm events that may be masked by using gridded precipitation data.

Hydrographs for prefire and postfire calibrated models using the Cloudcroft precipitation gage are shown together with observed streamgage daily flows and daily hyetograph for a prefire (2010) year and a postfire (2014) year (fig. 7). Daily streamflow rates were consistently greater for the postfire model than for the prefire model for both 2010 and 2014 climatic periods except for periods of sustained streamflow following extended rainfall periods (August 2010 and September 2014). The observed prefire streamflow hydrograph (2010) showed extended rising limbs and falling limbs in response to summer precipitation that were closely followed by the data from the prefire model hydrograph. Hydrographs from the observed streamflow and the postfire model (2014) were more flashy and responsive, with streamflow increasing almost immediately following most precipitation events. The observed postfire streamflow hydrograph showed sharp peaks in flow similar to the peaks simulated by the postfire model. Comparison of the distribution and magnitudes of prefire (2010) observed streamflow generally demonstrated a better match to prefire model results, and the postfire (2014) observed streamflow demonstrated a better match to postfire model results (fig. 7).

Cumulative hydrographs for prefire and postfire calibrated models (fig. 8) show similar behavior. In response to climatic conditions of both years $(2010,2014)$, the prefire model demonstrated a sharp increase in streamflow during a fairly concentrated period of surface runoff, with periods of prolonged, gradual increases in flow before and after the sharp increases. The postfire model responded with a series of sharp, flashy increases in streamflow throughout the entire season. Comparing the patterns of the cumulative observed hydrograph to simulated hydrographs in each year demonstrated a better match with the prefire model hydrograph pattern in 2010 and postfire model hydrograph pattern in 2014 (fig. 8).

The prolonged periods of gradual increases in streamflow for the prefire model results (figs. 7, 8) appeared to be consistent with a greater contribution of base flow under prefire conditions. An assessment of annual contributions for surface runoff and two base-flow components, interflow and groundwater flow, confirm this interpretation (fig. 9). In PRMS, interflow originates from the shallow soil zone, and groundwater flow originates from the groundwater reservoir (Markstrom and others, 2015). The prefire model had large contributions from the base-flow component in both climatic years $(2010,2014)$, whereas the greatest contribution to streamflow in the postfire model was surface runoff. The prefire model displayed much more interflow relative to the postfire model in the postfire year (2014). 


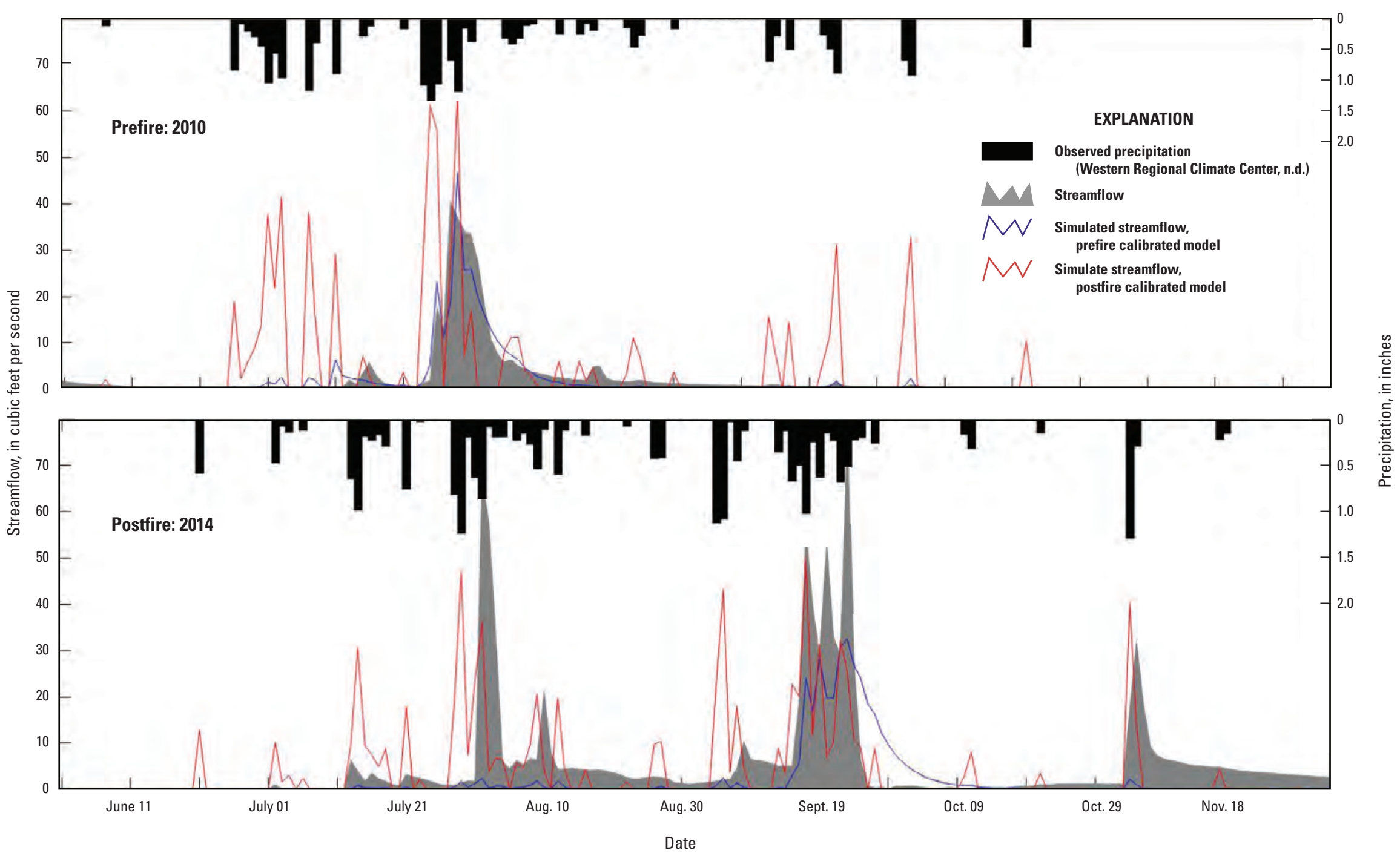

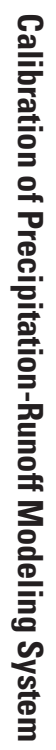

Figure 7. Observed and simulated streamflow and observed precipitation at the Cloudcroft raingage for prefire (2010) and postfire (2014) conditions, June through November, North Fork Eagle Creek subwatershed, New Mexico. 


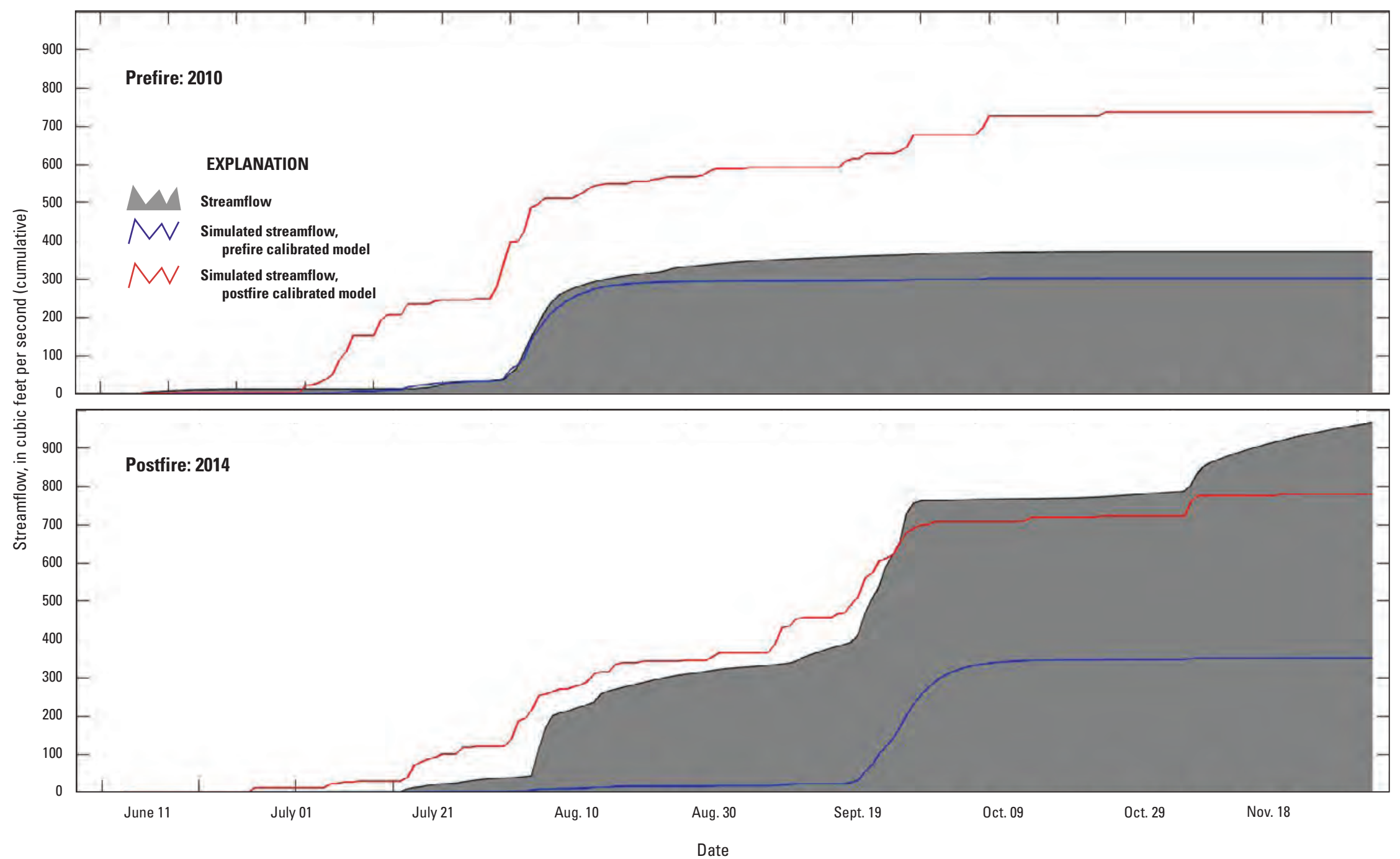

Figure 8. Observed streamflow and the calibrated Precipitation-Runoff Modeling System cumulative daily streamflow for prefire (2010) and postfire (2014) conditions, June through November, North Fork Eagle Creek subwatershed, New Mexico. 


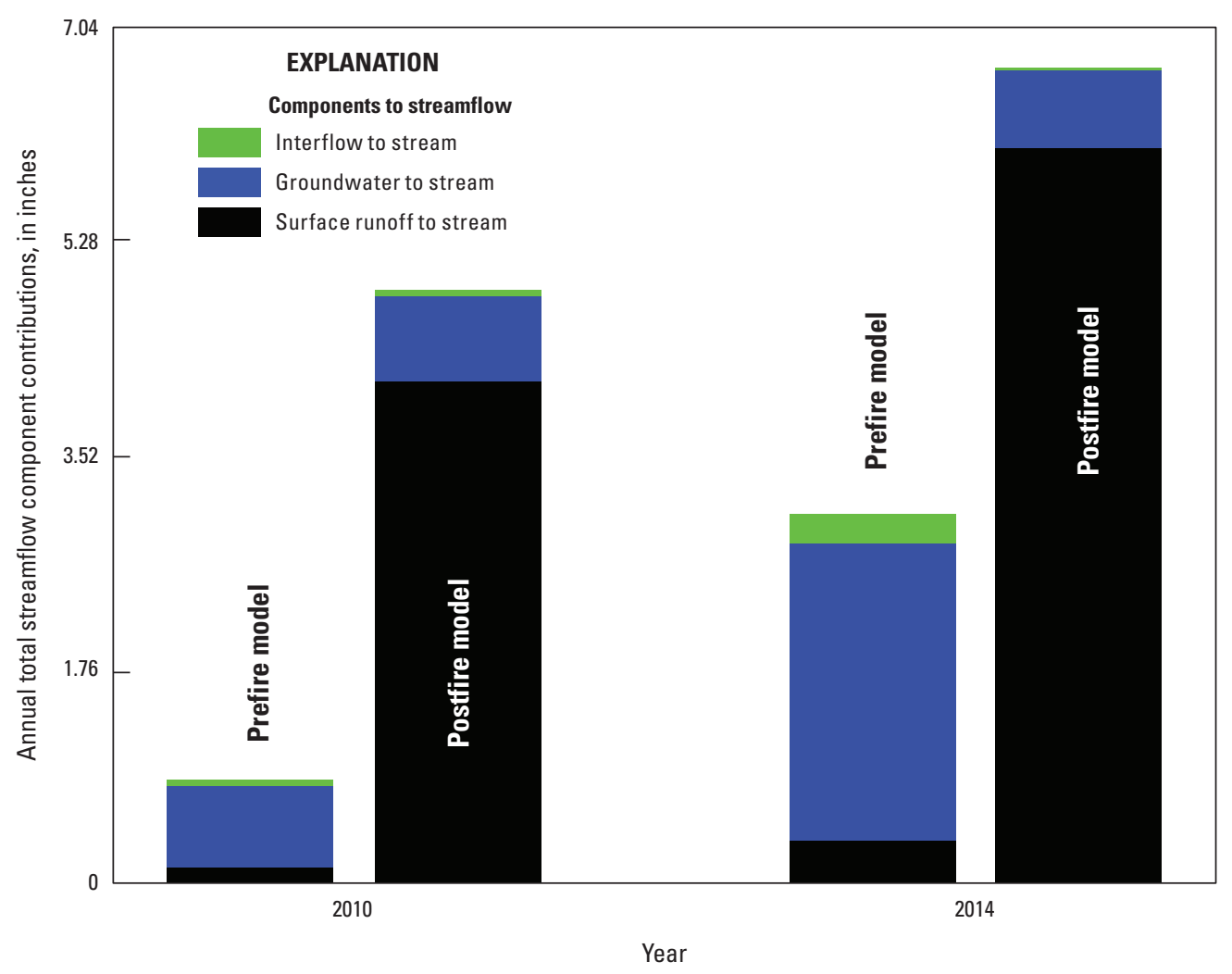

Figure 9. Annual total streamflow component contributions for prefire (2010) and postfire (2014) calibrated Precipitation-Runoff Modeling System models (May through October).

\section{Summary and Conclusions}

The Precipitation-Runoff Modeling System (PRMS) is widely used to simulate the effects of climate, topography, land cover, and soils on landscape-level hydrologic responses and streamflow. The U.S. Geological Survey, in cooperation with the New Mexico Department of Homeland Security and Emergency Management, developed procedures to apply the PRMS model to simulate the effects of fire on hydrologic responses.

A platform was created to provide a quasi-graphical user interface to easily query the Fourier amplitude sensitivity test (FAST) data by region and implemented to analyze national-scale sensitivity analysis (FAST) results at the local-basin scale. Results provided specific PRMS model calibration parameters that were most sensitive for simulating specific watershed processes at the hydrologic response unit (HRU) spatial scale. These results were applied toward selection of critical parameters that were used for subsequent model calibration.
Model calibration adjusted selected PRMS parameters from their default values by two methods. First, eight parameters were user defined on the basis of specific outside data and relations that were applied to the study area. Then, automated calibration using Let Us Calibrate (LUCA) adjusted the most sensitive parameters, as determined from the sensitivity analysis. Model calibration applied a gridded, daily precipitation dataset that captured the spatial heterogeneity across the study watershed. Model performance was assessed as satisfactory by using standard statistical measures for prefire (2007-12) and postfire (2014-15) periods.

A basic application of the calibrated model was demonstrated. The calibrated model was applied by using data from one precipitation gage to better represent effects of localized, extreme storms on postfire hydrologic response. The calibrated models for prefire and postfire conditions simulated streamflows with greater consistency for the corresponding (prefire or postfire) period of hydrographic record. Analysis of sources of streamflow contributions indicated that the effect of fire on streamflow was primarily due to the shift from streamflow dominated by base flow prior to fire to streamflow dominated by surface runoff after fire. 


\section{References Cited}

Archfield, S.A., Kennen, J.G., Carlisle, D.M., and Wolock, D.M., 2014, An objective and parsimonious approach for classifying nature flow regimes at a continental scale: River Research Applications, v. 30, p. 1166-1183.

Beven, K.J., 2002, Towards a coherent philosophy for environmental modeling-Proceedings of the Royal Society A: Mathematical, Physical and Engineering Sciences, v. 458, no. 2026, p. 2465-2484. [Also available at https:// doi.org/10.1098/rspa.2002.0986.]

Cerda, A., and Doerr, S.H., 2005, The influence of vegetation recovery on soil hydrology and erodibility following fire-An eleven-year investigation: International Journal of Wildland Fire, v. 14, no. 4, p. 423-437.

Daggupati, P., Pai, N., Ale, S., Douglas-Mankin, K.R., Zeckoski, R.W., Jeong, J., Parajuli, P.B., Saraswat, D., and Youssef, M.A., 2015, A recommended calibration and validation strategy for hydrologic and water quality models: Transactions of the ASABE, v. 58, no. 6, p. 1705-1719. [Also available at https://doi.org/10.13031/trans.58.10712.]

Darr, M.J., Rattray, G.W., McCoy, K.J., and Durall, R.A., 2014, Hydrogeology, water resources, and water budget of the upper Rio Hondo Basin, Lincoln County, New Mexico, 2010: U.S. Geological Survey Scientific Investigations Report 2014-5153, 72 p.

Doerr, S.H., and Cerda, A., 2005, Fire effects on soil system functioning-New insights and future challenges: International Journal of Wildland Fire, v. 14, no. 4, p. 339-342.

Doerr, S.H., Shakesby, R.A., and MacDonald, L.H., 2009, Soil water repellency-A key factor in post-fire erosion, in Cerda, A., and Robichaud, P.R., eds., Fire effects on soils and restoration strategies: Boca Raton, Fla., CRC Press.

Gleeson, T., Smith, L., Moosdorf, N., Hartmann, J., Dürr, H.H., Manning, A.H., van Beek, L.P.H., and Jellinek, A.M., 2011, Mapping permeability over the surface of the Earth: Geophysical Research Letters, v. 38, L02401. [Also available at https://doi.org/10.1029/2010GL045565.]

Harmel, R.D., Baffaut, C., and Douglas-Mankin, K.R., 2018, Review and development of ASABE Engineering Practice 621: Guidelines for calibrating, validating, and evaluating hydrologic and water quality models: Transactions of the ASABE, v. 61, no. 4, p. 1393-1401. [Also available at https://doi.org/10.13031/trans.12806.]

Harmel, R.D., Smith, D.R., King, K.W., and Slade, R.M., 2009, Estimating storm discharge and water quality data uncertainty—A software tool for monitoring and modeling applications: Environmental Modelling and Software, v. 24, p. 832-842. [Also available at https://doi.org/10.1016/j. envsoft.2008.12.006.]
Harmel, R.D., Smith, P.K., Migliaccio, K.W., Chaubey, I., Douglas-Mankin, K.R., Benham, B., Shukla, S., Muñoz-Carpena, R., and Robson, B.J., 2014, Evaluating, interpreting, and communicating performance of hydrologic/water quality models considering intended use-A review and recommendations: Environmental Modelling and Software, v. 57, p. 40-51. [Also available at https://doi.org/10.1016/j.envsoft.2014.02.013.]

Hay, L.E., Clark, M.P., Pagowski, M., Leavesley, G.H., and Gutowski, W.J., Jr., 2006, One-way coupling of an atmospheric and a hydrologic model in Colorado: Journal of Hydrometeorology, v. 7, p. 569-589. [Also available at https://doi.org/10.1175/JHM512.1.]

Hay, L.E., Leavesley, G.H., Clark, M.P., Markstrom, S.L., Viger, R.J., and Umemoto, M., 2007, Step wise, multiple objective calibration of a hydrologic model for a snowmelt dominated basin: Journal of the American Water Resources Association, v. 42, no. 4, p. 877-890. [Also available at https://doi.org/10.1111/j.1752-1688.2006.tb04501.x.]

Hay, L.E., and Umemoto, M., 2006, Multiple-objective stepwise calibration using Luca: U.S. Geological Survey Open-File Report 2006-1323, 25 p. [Also available at https://pubs.er.usgs.gov/publication/ofr20061323.]

Homer, C., Dewitz, J., Fry, J., Coan, M., Hossain, N., Larson, C., Herold, N., McKerrow, A., VanDriel, J.N., and Wickham, J., 2007, Completion of the 2001 National Land Cover Database for the conterminous United States: Photogrammetric Engineering and Remote Sensing, v. 73, no. 4, p. 337-341.

Kirchner, J.W., 2006, Getting the right answers for the right reasons-Linking measurements, analyses, and models to advance the science of hydrology: Water Resources Research, v. 42, no. 3, p. 1-5. [Also available at https://doi. org/10.1029/2005WR004362.]

Konrad, C.P., 2004, Simulated water-management alternatives using the Modular Modeling System for the Methow River Basin, Washington: U.S. Geological Survey Open-File Report 2004-1051, 12 p.

Kottek, M., Grieser, J., Beck, C., Rudolf, B., and Rubel, F., 2006, World map of the Köppen-Geiger climate classification updated: Meteorologische Zeitschrift, v. 15, no. 3, p. 259-263. [Also available at https://doi. org/10.1127/0941-2948/2006/0130.]

Leavesley, G.H., Lichty, R.W., Troutman, B.M., and Saindon, L.G., 1983, Precipitation-Runoff Modeling SystemUser's manual: U.S. Geological Survey Water-Resources Investigations Report 83-4238, 207 p. [Also available at https://pubs.er.usgs.gov/publication/wri834238.]

Liu, Y., Stanturf, J., and Goodrick, S., 2010, Trends in global wildfire potential in a changing climate: Forest Ecology and Management, v. 259, no. 4, p. 685-697. [Also available at https://doi.org/10.1016/j.foreco.2009.09.002.] 
MacDonald, L., and Huffman, E., 2004, Post-fire soil water repellency_Persistence and soil moisture thresholds: Soil Science Society of America Journal, v. 68, p. 1729-1734. [Also available at https://doi.org/10.2136/sssaj2004.1729.]

MacDonald, L.H., and Stednick, J.D., 2003, Forests and water-A state-of-the-art review for Colorado: Fort Collins, Colorado Water Resources Research Institute, Colorado State University, CWRRI Completion Report No. 196.

Markstrom, S.L., Hay, L.E., and Clark, M.P., 2016, Towards simplification of hydrologic modeling - Identification of dominant processes: Hydrology and Earth System Sciences Discussions, (January), p. 1-33. [Also available at https:// doi.org/10.5194/hess-2015-508.]

Markstrom, S.L., Regan, S., Hay, L.E., Viger, R.J., Webb, R.M.T., Payn, R.A., and LaFontaine, J.H., 2015, PRMS-IV, the Precipitation-Runoff Modeling System, version 4: U.S. Geological Survey Techniques and Methods, book 6, chap. B7, 158 p. [Also available at https://doi.org/10.3133/ tm6B7.]

Martin, D.A., and Moody, J.A., 2001, Comparison of soil infiltration rates in burned and unburned mountainous watersheds: Hydrological Processes, v. 15, p. 2893-2903. [Also available at https://doi.org/10.1002/hyp.380.]

Matherne, A.M., Myers, N.C., and McCoy, K.J., 2010, Hydrology of Eagle Creek Basin and effects of groundwater pumping on streamflow, 1969-2009: U.S. Geological Survey Scientific Investigations Report 2010-5205, 73 p.

Moeser, C.D., Douglas-Mankin, K.R., Mitchell, A.C., and Chavarria, S.B., 2018, Model input and output for prefire and postfire hydrologic simulations in the upper Rio Hondo Basin, New Mexico using the Precipitation-Runoff Modeling System (PRMS): U.S. Geological Survey data release, https://doi.org/10.5066/F7KD1X7Q.

Moeser, D., Mazzotti, G., Helbig, N., and Jonas, T., 2016, Representing spatial variability of forest snowImplementation of a new interception model: Water Resources Research, v. 52, no. 2, p. 1208-1226. [Also available at https://doi.org/10.1002/2015WR017961.]

Moeser, D., Morsdorf, F., and Jonas, T., 2015a, Novel forest structure metrics from airborne LiDAR data for improved snow interception estimation: Agricultural and Forest Meteorology, v. 208, p. 40-49. [Also available at https://doi. org/10.1016/j.agrformet.2015.04.013.]

Moeser, D., Stähli, M., and Jonas, T., 2015b, Improved snow interception modeling using canopy parameters derived from airborne LiDAR data: Water Resources Research, v. 51, no. 7, p. 5041-5051. [Also available at https://doi. org/10.1002/2014WR016724.]
Moody, J.A., and Martin, D.A., 2001, Hydrologic and sedimentologic response of two burned watersheds in Colorado: U.S. Geological Survey Water-Resources Investigations Report 01-4122, 142 p.

Moriasi, D.N., Arnold, J.G., Van Liew, M.W., Binger, R.L., Harmel, R.D., and Veith, T.L., 2007, Model evaluation guidelines for systematic quantification of accuracy in watershed simulations: Transactions of the ASABE, v. 50, no. 3, p. 885-900.

Moriasi, D.N., Gitau, M.W., Pai, N., and Daggupati, P., 2015a, Hydrologic and water quality models-Performance measures and evaluation criteria: Transactions of the ASABE, v. 58, no. 6, p. 1763-1785. [Also available at https://doi.org/10.13031/trans.58.10715.]

Moriasi, D.N., Zeckoski, R.W., Arnold, J.G., Baffaut, C., Malone, R.W., Daggupati, P., Guzman, J.A., Saraswat, D., Yuan, Y., Wilson, B.N., Shirmohammadi, A., and Douglas-Mankin, K.R., 2015b, Hydrologic and water quality models - Key calibration and validation topics: Transactions of the ASABE, v. 58, no. 6, p. 1609-1618. [Also available at https://doi.org/10.13031/trans.58.11075.]

Natural Resources Conservation Service, U.S. Department of Agriculture, 2012, Soil Survey Geographic (SSURGO) Database: Natural Resources Conservation Service website, accessed July 10, 2013, at https://sdmdataaccess.sc.egov. usda.gov.

Regan, R.S., Markstrom, S.L., Hay, L.E., Viger, R.J., Norton, P.A., Driscoll, J.M., and LaFontaine, J.H., 2018, Description of the National Hydrologic Model for use with the Precipitation-Runoff Modeling System (PRMS): U.S. Geological Survey Techniques and Methods, book 6, chap. B9, 38 p., accessed June 10, 2016, at https://doi. org/10.3133/tm6B9.

Rubel, F., Brugger, K., Haslinger, K., and Auer, I., 2017, The climate of the European Alps-Shift of very high resolution Köppen-Geiger climate zones 1800-2100: Meteorologische Zeitschrift, v. 26, no. 2, p. 115-125, accessed May 2017 at http://koeppen-geiger.vu-wien.ac.at/.

Ryan, K.C., and Opperman, T.S., 2013, LANDFIRE-A national vegetation/fuels data base for use in fuels treatment, restoration, and suppression planning: Forest Ecology and Management, v. 294, p. 208-216.

Saraswat, D., Frankenberger, J.R., Pai, N., Ale, S., Daggupati, P., Douglas-Mankin, K.R., and Youssef, M.A., 2015, Hydrologic and water quality models-Documentation and reporting procedures for calibration, validation, and use: Transactions of the ASABE, v. 58, no. 6, p. 1787-1797. [Also available at https://doi.org/10.13031/trans.58.10707.] 
Sauer, V.B., and Meyer, R.W., 1992, Determination of error in individual discharge measurements: U.S. Geological Survey Open-File Report 92-144, 21 p.

Sherson, L.R., and Rice, S.E., 2015, Water resources during drought conditions and postfire water quality in the upper Rio Hondo Basin, Lincoln County, New Mexico, 2010-13: U.S. Geological Survey Scientific Investigations Report 2015-5086, 56 p., https://doi.org/10.3133/sir20155086.

Snyder, J., Banks, A., Brown, P., and Lovely, C., 2012, 2012 Little Bear Fire, BAER hydrology report: U.S. Department of Agriculture, Forest Service, Southwestern Region, Lincoln National Forest, 20 p.

Terranova, O., Antronico, L., Coscarelli, R., and Iaquinta, P., 2009, Soil erosion risk scenarios in the Mediterranean environment using RUSLE and GIS-An application model for Calabria (southern Italy): Geomorphology, v. 112, p. 228-245. [Also available at https://doi.org/10.1016/j. geomorph.2009.06.009.]

Thornton, P.E., Thornton, M.M., Mayer, B.W., Wei, Y., Devarakonda, R., Vose, R.S., and Cook, R.B., 2016, Daymet: Daily surface weather data on a 1-km grid for North America, version 3: Oak Ridge, Tenn., ORNL DAAC accessed June 10, 2016, at https://doi.org/10.3334/ ORNLDAAC/1328.

Tillery, A.C., and Matherne, A.M., 2013, Postwildfire debris-flow hazard assessment of the area burned by the 2012 Little Bear Fire, south-central New Mexico: U.S. Geological Survey Open-File Report 2013-1108, 15 p., 3 pls., accessed June 10, 2016, at http://pubs.usgs.gov/ of/2013/1108/.

Toney, C., Shaw, J.D., and Nelson, M.D., 2009, A stem-map model for predicting tree canopy cover of Forest Inventory and Analysis (FIA) plots, in McWilliams, W., Moisen, G., and Czaplewski, R., eds., Forest Inventory and Analysis (FIA) Symposium 2008: October 21-23, 2008, Park City, Utah: Fort Collins, Colo., U.S. Department of Agriculture, Forest Service, Rocky Mountain Research Station, Proc. RMRS-P-56CD, 19 p.

Turnipseed, D.P., and Sauer, V.B., 2010, Discharge measurements at gaging stations: U.S. Geological Survey Techniques and Methods, book 3, chap. A8, 87 p. (Also available at https://pubs.usgs.gov/tm/tm3-a8/.)

U.S. Geological Survey, 2013, LANDFIRE existing vegetation type layer: U.S. Geological Survey, accessed November 2016 at https://landfire.cr.usgs.gov/distmeta/servlet/gov. usgs.edc.MetaBuilder?TYPE=HTML\&DATASET=FBE.
U.S. Geological Survey, 2018a, GeoMAC - Geospatial MultiAgency Coordination Wildland Fire Support: GeoMAC Wildland Fire Support and U.S. Geological Survey website, accessed January 2018 at https://rmgsc.cr.usgs.gov/ outgoing/GeoMAC/.

U.S. Geological Survey, 2018b, USGS water data for the Nation: U.S. Geological Survey National Water Information System database, accessed January 2018 at https://doi. org/10.5066/F7P55KJN.

Vieira, D., Fernández, C., Vega, J., and Keizer, J., 2015, Does soil burn severity affect the post-fire runoff and interrill erosion response? A review based on meta-analysis of field rainfall simulation data: Journal of Hydrology, v. 523, p. 452-464. [Also available at https://doi.org/10.1016/j. jhydrol.2015.01.071.]

Viger, R.J., 2014, Preliminary spatial parameters for PRMS based on the Geospatial Fabric, NLCD2001 and SSURGO: U.S. Geological Survey, accessed June 10, 2016, at http:// dx.doi.org/10.5066/F7WM1BF7.

Viger, R.J., and Bock, A., 2014, GIS features of the Geospatial Fabric for National Hydrologic Modeling: U.S. Geological Survey, accessed June 10, 2016, at http://dx.doi.org/ doi:10.5066/F7542KMD.

Western Regional Climate Center, [n.d.], Cloudcroft, New Mexico (291931) period of record monthly climate summary, September 1, 1987, to June 10, 2016, accessed June 10, 2017, at https://wrcc.dri.edu/cgi-bin/cliMAIN. pl?nm1931.

Wisner, R.H., 2004, Upper Rio Hondo Watershed Restoration Action Strategy, 2d ed.: The Upper Hondo Watershed Coalition, Ruidoso River Association, N. Mex., accessed June 10, 2016, at https://www.env.nm.gov/swqb/wps/ WRAS/Upper_Hondo_13060008_WRAS_Apr_2004.pdf.

Yazzie, K., and Chang, H., 2017, Watershed response to climate change and fire-burns in the Upper Umatilla River Basin, USA: Climate, v. 5, no. 1, p. 7. [Also available at https://doi.org/10.3390/cli5010007.]

Yuan, Y., Khare, Y., Wang, X., Parajuli, P.B., Kisekka, I., and Finsterle, S., 2015, Hydrologic and water quality modelsSensitivity: Transactions of the ASABE, v. 58, no. 6, p. 1721-1744. [Also available at https://doi.org/10.13031/ trans.58.10611.]

Zeckoski, R.W., Smolen, M.D., Moriasi, D.N., Frankenberger, J.R., and Feyereisen, G.W., 2015, Hydrologic and water quality terminology as applied to modeling: Transactions of the ASABE, v. 58, no. 6, p. 1619-1635. [Also available at https://doi.org/10.13031/trans.58.10713.] 
For more information about this publication, contact

Director, New Mexico Water Science Center

U.S. Geological Survey

6700 Edith Blvd NE

Albuquerque, New Mexico 87113

For additional information, visit

https://www.usgs.gov/centers/nm-water

Publishing support provided by

Lafayette Publishing Service Center 



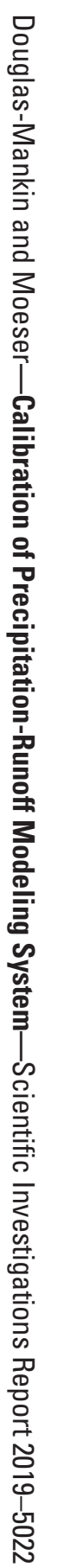

